CORNELIS CH. GOSLINGA

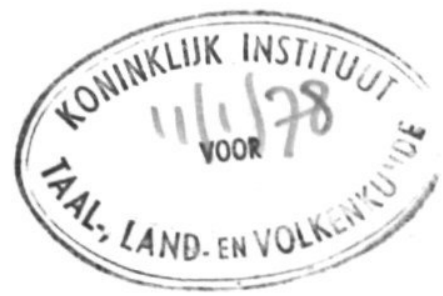

\title{
CURAÇAO AS A SLAVE-TRADING CENTER DURING THE WAR OF THE SPANISH SUCCESSION (1702-1714)
}

'The War of the Spanish Succession,' wrote Frank Taylor in his celebrated study on Marlborough, 'is a perfect example of the vices and defects of a coalition.' 1 Unity of purpose and harmony of action were wholly sacrifticed to the selfish and short-sighted ambitions of the vast confederacy's indivudual members. The Emperor's goals differed considerably from those of the Maritime Powers and the latter, competing savagely with each other in the East- and West-Indian markets, emerged as rather untrustworthy allies in the common European cause.

With the advent of the eighteenth century, trade - including the African slave trade - provided the cornerstone for the European powers' colonial empires. 2 Prevailing over all other considerations, trade came to govern eighteenth century politics and play a prominent role in that century's first major conflict. Only some one unaware of its underlying causes, could take this struggle for a dynastic one. 3 It was neither for this king nor for that emperor that the European nations drew their swords, but solely to further their own ambitions and the West Indies were - at least for one of them - the most coveted price. In other words, the War of the Spanish Succession was, far more than any other preceding conflict, a war for economic goals. Great Britain wanted the SpanishAmerican market, yet fear of competition from the enemy - the French - or the ally - the Dutch - inspired the disingenious diplomacy for which the country became known as 'perfidious Albion.'

Britain's claims, as far as the continent was concerned, were, undoubtedly, less pressing than those of the Netherlands or of the Emperor. She responded coolly to the Partition Treaty concocted between William III and Louis XIV.4 Charles II's will put an end to all speculation and scheming and, said to be written under the influence of the Pope who dreaded the presence of 
both the Dutch and the English in South America, it convinced Louis XIV to put himself and France solidly behind his grandson, the Duke of Anjou.

For the time being, William III seemed willing to recognise the Duke as King of Spain. But Louis' careless exclamation that the Pyrenees had ceased to exist certainly did not fail to irritate Great Britain. Only too well did she realize that if Louis controlled the governments of both France and Spain, he would be in a position to clear the way for a monopoly of French trade, particularly where Spanish America was concerned. 5 An additional sign pointing ominously in that direction was the treaty of alliance between Spain and Portugal, concluded at Lisbon in June, 1701.

Among the commercial advantages France expected to derive from the accession of the Duke of Anjou to the Spanish throne was the asiento, the right to import blacks into the Spanish American colonies. With this in mind she had already helped to bring about the adjustment of several disputes between the Portuguese African Company and the Spanish government. Soon afterwards, the French negotiated the concession of the asiento to their Guinea Company. In September, 1701, King Philip V signed the agreement bestowing upon the French company the exclusive right during the next ten consecutive years, beginning on May 1, 1702, to introduce black slaves into Spanish America.6

England immediately understood that the new arrangement seriously threatened her West Indian interests. After three wars with the Dutch the latter, though not yet eliminated in the commercial arena, no longer posed a political challenge to Albion's arrogance, and the Acts of Navigation kept their competition sufficiently well under control. A combined French-Spanish Crown might well become a far more serious menace to the English. Consequently, their first move was to bring the Portuguese over to their side, and a fleet was dispatched to the mouth of the Tagus to convince the Portuguese king of the legitimacy of the English rationale. Should Charles of Austria become King of Spain instead, the restoration of some Portuguese colonies would be a just reward for Portugal's support of the Anglo-DutchAustrian cause.

Britain's next move was to gain control over the West Indian trade. In return for an Austrian promise not to interfere with English or Dutch interests in Spanish America, King William III agreed that the Maritime Powers should conquer the region in the Emperor's name. This offensive/defensive alliance between Aus- 
tria, Great Britain, the United Provinces, and Portugal, concluded after William's death, was accepted by Queen Anne who, initially, adhered to William's policy. ${ }^{7}$ It proposed that an Anglo-Dutch fleet would attempt to bring Spanish America under the sway of the Austrian eagle. Charles would then grant free trade to the English and the Dutch in the newly conquered colonies under his rule.

With the war going well for the Allied Powers, in 1707, Queen Anne ventured to approach Charles for the conclusion of a treaty bearing more specificially on Spanish America. A separate provision would be to sanction the formation of an Anglo-Spanish Company governing Spanish American trade or, if this would prove impractical, give Englishmen the same privileges that the Spaniards already possessed with respect to this commerce. In this draft the Dutch were not mentioned. Apparently, Queen Anne had come to the realization that English and Dutch interests in the West were too competitive and best kept apart.

Hence it was this West Indian trade which was at the heart of the constant friction which engulfed the Maritime Powers, and which ultimately resulted, particularly after 1709 , in a paralyzing stalemate on the European battlefield. It may be true that the Queen honestly intended to follow in William's footsteps, but she was a woman uncannily clever in judging the mood of her people and did not choose to impose her will when the House of of Commons, freely elected by the landed interests, arduously pursued a policy of peace after several years of uninterrupted warfare. 8

While the Whigs were unable to come up with an alternative to continuing the war - a war by far more vital to both the United Provinces and the Empire - Toryism gained ground. Once the spectre of a united France and Spain under one crown had faded away and Gibraltar had been conquered, Queen Anne quickly lost all interest in the continental power scrambles.

The United Provinces, on the other hand, doggedly continued the war aiming simultaneously to safeguard her trade in the East and the West and to protect her undefended southern border. Great Britain, quite amenable to help her ally achieve the latter goal, having no territorial designs on the continent herself, instead, concentrated all her efforts on Spanish America, her West Indian trade, and the asiento. The fatal mistake of the Dutch lay not so much in their distrust of an ally whose priorities had shifted, but in a wrong evaluation of their own priorities subor- 
dinating their West Indian interests to the dubious protection of a series of barrier fortresses on their southern flank. Great Britain, well aware of this prevailing attitude, profited from it. On the other hand, did she really have legitimate grounds to complain about some of the activities of her maritime ally? 'The Dutch should do more by sea than of late years they have been used to do,' wrote Bolingbroke in January, 1711,9 while their conduct both on the African coast and in the East Indies were 'displeasing the English authorities to a high degree.' 10 However, at this stage, Queen Anne was probably still desirous to cultivate a harmonious relationship with the Dutch, although the change from a Whig to a Tory Cabinet upset the latter to no small degree.

At the same time that Great Britain, without her ally's acquiescence, was negotiating the asiento with French and Spanish representatives, she realized only too well that the Dutch, obsessed with the fear of their competitor gaining commercial and economic advantages at their expense, could stealthily conspire to go at the same goal on their own making, and make the British the dupes of a peace, as they, by now, felt they had been of the war.

Great Britain was indeed getting tired of the war and the setbacks she suffered, cumulating in Charles III becoming Emperor of Austria, were no incentives to continuing ad infinitum. She felt betrayed by her ally - or pretended betrayal - because the Dutch had 'lessened their proportions in every part of the war, even in that of Flanders, on the pretense of poverty.' 11 Besides, by now, she had practically achieved her own goals which were the obliterating of French (and Spanish) trade in the West Indies, the acquisition of the asiento, the elimination of Dutch competition in the slave trade, and the assurance that the crowns of France and Portugal would remain separated.

The changed British mood became rather obvious and did not fail to alarm the Dutch ally who, due to the humiliation of the French at Geertruidenberg, was powerless to react and utterly at the mercy of the English. Because of the unrealistic demand by the Dutch that Louis XIV should undertake either to persuade Philip V or to compel him by means of force to renounce the Spanish throne, the French king had adamantly refused to address himself to the Dutch or to negotiate directly with them.12 Thereupon, the new Tory leader - Robert Harley, Earl of Oxford - wishing to conceal the French overtures from the ally, asked the French to submit proposals which the English, in turn, would lay before the Dutch. This British attitude - a French diplomatic 
victory - made any Dutch initiative impossible. Whatever choices the Dutch would face would be at the discretion of the British who, of course, were not about to lose sight of their own interests. In a conference on August 1711, between Great Britain and France, the British insisted that only their own demands and not those of their allies were at issue. They probably did not consider this an act of prevarication. 'Whatever occurs to us concerning the common interest will always be nakedly offered to the Confederacy of the States. Whatever relates to the private interest of Britain, as far as the concurrence of the Dutch is necessary or reasonable, will also, without any reserve, be communicated.' 13 This statement left, of course, the door wide open for diplomatic detours and separate negotiations which were soon concluded and which gave, in September, 1711, the English the coveted asiento. 14

Were the Dutch aware of British duplicity? The evidence is inconclusive. At the end of August and again at the beginning of September, 1711, the Earl of Oxford was informed that the Dutch 'think you are running away with the trade, and that you are far advanced and keep them in the dark.' 15 Was Queen Anne sincere when she gave the Earl of Strafford, her representative in Utrecht, the following instruction: 'You can assure them that we have made no stipulation for ourselves which may clash with the interests of Holland.' 16 Yet, in November, 1711, Oxford clearly deceived Buys, the extra-ordinary Dutch envoy in London, with the assurance that Great Britain had not achieved anything neither in Spain nor in the Spanish West Indies. Great Britain was determined to deprive the Dutch of any basis for claiming a share in the asiento or in any other advantage the Spanish American trade might yield which they, themselves, by now were sure to obtain from Philip V.17

The humiliating role of the Dutch in the peace negotiations of Utrecht is well known. As Acton bluntly puts it: 'France concluded a disastrous war with a triumphant settlement.' 18 The United Provinces, never realizing its inherent weakness, gained the barrier treaty, an expensive and empty guarantee, but the Spanish American trade passed her by. 'On traitera de la paix chez vous, pour vous et sans vous' were the sneering words the Dutch representativers had to swallow from their French colleague De Polignac. On the other hand, Great Britain betrayed her ally for the sake of mere profit, and allowed herself to become deeper involved in the slave trade. 


\section{Caribbean aspects of the War}

Against this European background the island of Curaçao, a small Dutsch speck in the Caribbean, had tottered along throughout the disastrous years of the war miraculously surviving the threat of occupation by France and the bankruptcy of its own shameful slave trade.

The two European allies, referred to as the Maritime Powers, were not on such good footing at the other side of the Atlantic as their role in the first years of the War of the Spanish Succession would indicate. In the Caribbean constant friction, mutual vilification, and defamation caused by jealousy and commercial rivalry were the order of the day. In spite of three Anglo-Dutch wars and a rigorous application of successive Navigation Laws, the Dutch managed to survive and, worse, to offer stiff competition to the British, a fact which caused many a full blooded Englishman to swell with indignation. Although not reaching the extreme despair of Pepys' exclamation that 'the Devil shit Dutchmen', many governors of the West Indian plantations voiced their feelings clearly. 'If the Summer Islands be overtaken by surprise or otherwise by the French or Dutch, which may be easily done at this time with 500 men,' wrote Governor Randolph of the Bermudas, 'they will command all the trade in these parts of the world.' 19 English worries with respect to Dutch inroads in their commercial pretensions played a mayor role in the correspondence of British West Indian governors with the home government. In this part of the world the Dutch ally was, henceforth, considered almost an enemy. A True Account of Several Grand Abuses in Trade and the Proper Remedy stated that 'the merchants of New York have gotten their estates by the Curesaw trade' and pointed toward the excessive intercourse between Barbados and the Dutch West Indian settlements. 20 A similar heavy traffic existed between the Bermudas and Curaçao 'where they manage to trade with the Spaniards,' 21 and with most other, if not all British West Indian islands. It even extended to the continental colonies, from Carolina up to New England. While provisions and slaves were the main comodities Curaçao deliverd, it is interesting to itemize these provisions. With the exception of logwood and salt (and slaves) which were included in the monopoly of the Dutch West India Company, the merchants of Curaçao imported sugar, pork, 
flour, biscuit, and other dry goods plus tobacco from the British, French, and Spanish colonies in return for all sorts of lining, manufactured goods, hardware, wines (expecially claret and Madera), onions, cabbage, brandy, rum, sugar, tobacco, molasses, flour, and cacao. 22 Of course, most, if not all, of this trade was illegal, and the smuggling of blacks probably outranked in importance all items combined. 23

Underlying the official complaints about the smuggling and this illegal inter-island and inter-colonial trade, 23 which seemed to have flourished in spite of all prohibiting regulations, is a good old dose of envy aimed at the Dutch competitor who seemed to succeed where the Englishman had failed. 'English trade is very dull,' is only one example of the type of outcry with which the Council of Trade and Plantations was deluged.24 This animosity was further exacerbated by the irritating fact that the Dutch, before and after 1702, when war broke out, maintained an excellent relationship with the inhabitants of the Spanish American mainland - though not always with the authorities - who exchanged produce, and silver or gold for blacks. 25 Could it be that these envious English officials had suggested that the mother country attack Curaçao and did the War of the Spanish Succession destroy that design? 'As for Curaçao, if it were sunk under water, it would be better for England by 5 or 600,000 pound in one year,' expresses quite well the prevailing mood. 26 The Governor of the Bermudas, Edward Randolph, wrote to the Council of Trade and Plantations in January, 1700 when war was still far from the horizon, that he had sent them a sketch of Curaçao "which shows the harbour.' This map was certainly not sent for peaceful purposes. 27

This English attitude soured relations with the Dutch in the Caribbean to no small extent, it also provided the Anglo-Dutch alliance with an extra dimension. 'The Dutch are notorious for their illegal trade,' 28 'the Dutch will reap the benefit from the English,' 29 'the Acts of Trade and the $4 \frac{1}{2} \%$ act encouraged sending of many millions of pounds of sugar to St. Eustatius, Curaçao, and St. Thomas, ' 30 'the Curaçao trade is carried on more than ever,' 31 and 'all illegal trade is carried on there,' 32 are but a handful of quotes expressing the spiteful feelings of many English officials.

Many Dutchmen equated these remarks with an undisguised defamation of their national character. In Lord Cornbury's letter to the Council of Trade and Plantations, it was implied that all 
Dutch were cowards, while the Governor of New York, a city which at that time still counted a powerful Dutch element among its inhabitants, refers to the Dutch as 'generally the meanest of the people, men extremely ignorant of all things.' 33 Did these and other vilifications have some impact in the home country? It is difficult to guess their weight, but one thing is certain: there was in the British Caribbean an undeniable resentment against the Dutch and a deep-seated fear of their commercial prowess. 34

Within the frame of these two dimensions - a European war with Great Britain as an unreliable ally and the Caribbean stage presenting a neverending rivalry - the Dutch West India Company made every effort to sustain its main business, the slave trade. It was not easy. Heinsius, the Grand Pensionary, professed only a lukewarm interest in West Indian affairs. The end of the Coymans Asiento dealt a heavy blow to the WIC's slave trade, from which it, nevertheless, managed to recover to gain possession of another asiento in 1691.35 Years of rapid growth followed only to be interrupted by a recession which lasted until 1697 , when a new contract was signed which called for the delivery of 2,500 - 3,000 blacks per year to Curaçao. 36 Again the trade flourished and declined. Negotiations next took place with the Portuguese African Company which, since 1693, had been in control of the asiento. 37 At the turn of the century trade was at a very low tide, and when, in 1701, the Portuguese were forced to hand over their asiento rights to the French, the future for the Dutch company looked black indeed, in spite of the fact that, as Postma rightly observes, single nations did no longer completely control the asiento. When chances were that the Archduke Charles would be King of Spain - namely in 1703 and again in 1706 and 1707 - the Dutch company again exerted itself to gain a privileged position. In those years the slave trade was doing rather well, and the only obstacle to stand in the way of the WIC's Board of X was the uncompromising stand proffered by Great Britain, the ally. Not fully backed by the Dutch government, the WIC emerged the loser in this confrontation.

During the War of the Spanish Succession Curaçao was presided over by Nicolaas van Beek (acting governor 1700-1701, governor 1701-1704), Jacob Beck (1704-1708), his brother Abraham Beck (1708-1710), and Jeremias van Collen (acting governor 1710-1711, governor 1711-1715). Archival research, although far from completed, is uncovering a revealing picture of Dutch slave trading in this critical period. 
Research of Dutch slave trading

Mention should be made here of Johannes Postma's recent doctoral thesis The Dutch Participation in the African Slave Trade, cited above. Postma discusses this trade from the African standpoint and covers the period from 1675 through 1795 . In contrast, we limit ourselves to a much shorter period, the years of the War of the Spanish Succession, with the main focus on the island of Curaçao, the receiving end of this trade. Our research will, for the period mentioned, not only supplement Postma's dates but also introduce some alternative information and explain, it is hoped, some apparent contradictions between his findings and ours. This does not mean that everything related to the subject has been said. Research in this field - as far as the Dutch participation is concerned - has only just been started. Many treatises have explored the trading exploits of the various European powers along the African coast, yet, hitherto not much has been written concerning the activities of the Dutch on the other side of the Atlantic. Postma's pioneering study will, we expect, stimulate studies like ours. We realize, of course, that most conclusions we made will have to be tentative until after the records of the Dutch West India Company have been more fully explored. 38

The Second or New Dutch West India Company, founded in 1674 succeeded the bankrupt first institution of that name, and was, during the long century of its existence - it was liquidated in 1791 - mainly a slave trading company. Although, as mentioned, many dates are still lacking and much research remains to be done, Postma brings substantial new data to light as to its first 25 years. During $1675-1699$, for instance, the Caribbean port of Curaçao admitted at least 22 slavers whose cargoes (known in Dutch as armazoenen) and final destination have been verified. These ships unloaded a total of 9876 blacks, 39 while an additional 7800 blacks were deliverd by an unknown number of ships, to be divided between Curaçao and Surinam. It may be safely assumed that Curaçao absorbed half of these. A thorough examination of Postma's dates - which are probably not complete - brings the total of blacks disembarked at Willemstad by the Dutch West India Company to at least 13,500.40 This trade, although frequently encountering obstacles and interruptions, especially during the Nine Years' War - King William's War nevertheless, appears to have survived those crises with minimal consequences. 
Although the War of the Spanish Succession was to deal a severe blow to the West India Company's slave trade, at the turn of the century, its prospects were highly propitious. In August, 1700 , the slave-trade commissioner Gerard Luls, at Willemstad, Curaçao, wrote the Board of the WIC: 'I can assure you, gentleman, that if we had two or three cargoes of blacks [armazoenen] we could sell them immediately, and even the non-deliverable slaves [ the sick ones and the so-called mancquerons, slaves with some defect ] would bring a good price, because there is a dire need for them. 41

For a better understanding of this statement, the following may serve to clarify. High on the Governor of Curaçao's list of priorities, after the arrival of a slaver from Africa, was a separation of the blacks. A careful selection was made separating those considered to be mentally and physically healthy, and consequently marketable, the so-called Piezas de India, from the unsalable slaves, the sick ones and those who were too old or had defects, the mancquerons. 42 This discriminatory process was performed by a three-men committee, appointed by the governor. 43 The Piezas de India were sold at fixed export rates to foreign clients, at times via the representatives of the asiento on Curaçao. The mancquerons and sick slaves were immediately disposed of at a public auction.

Thus, for instance, when the slaver 't Wapen van Holland disembarked its remaining 453 blacks from an armazoen of 664 ( 205 had not survived the mid passage and 6 had died in port) the selection was made as follows:

141 males Piezas de India

70 females (with 2 babies) id.

24 boys (between 12 and 15 years) each $2 / 3$ Pieza de India 16

10 boys (between 8 and 12 years) each $1 / 2$ Pieza de India 5

8 girls (between 12 and 15 years) 2/3 Pieza de India 5

4 girls (between 8 and 12 years) $1 / 2$ Pieza de India 2

257 heads

Piezas de India 239

The unfit blacks were thus described:

73 male mancquerons

44 female id. with 2 babies

30 males sick

37 females sick with 2 babies 
5 boys mancquerons

6 boys sick

1 girl sick

196 mancquerons and sick slaves

In contrast of the Piezas de India who always brought a fixed price - first 100 pesos, later 108 - the manquerons were sold at public auction for as little as one and as much as 99 pesos. 44

\section{W.I.C. and lorredraaiers}

While on the African coast the price of blacks was constantly inflated - in the period from 1675 to the Peace of Utrecht Postma mentions and increase from 25 to 45 guilders - the WIC had to cor.tend not only with the stiff competition of other European nations, especially the English and the French, but also with that of the so-called lorredraaiers or interlopers, those slavers outfitted by Dutchmen themselves who tried to dodge the Company's monopoly. With practically no overhead nor any maintenance costs for the fortresses that the Company had to staff with garrisons and other employees, these lorredraaiers were able to offer higher prices to the African vendors and sell at lower prices than the WIC at the other side of the Atlantic. The Company's employees also had to abide by the Marktbrief or Price Table, which listed maximum allowable prices in their purchase of blacks. No WIC servant was permitted to pay more than the authorized sum, while, of course, the lorredraaier had much more leeway and operated without these strangling restrictions. This situation frequently forced the WIC slavers to remain on the African coast for weeks and even months before they managed to assemble a worthwhile cargo. 45 Another consequence of the competition and the paralyzing delays was the fact - often pointed out by successive governors of Curaçao - that the slavers would leave the coast only partially loaded. 46

\section{Problems with Cartagena}

But if the African side of the slave trade was beset by many problems, these were well matched by the troubles which converged on the Caribbean side. The Graaf van Laarwijk provides an excellent example of a slaver becoming mixed up in local quarrels without any fault of its captain but to the great detriment of the 
WIC. Destined for Cartagena, together with another Dutch slaver, it was prohibited from entering that port as a result of prevailing tensions between the governor and the local asentista, Don Gaspar de Andrade. Consequently, both ships had to disembark their armazoenen at Playa Grande without receiving any payment whatsoever. 47 These experiences made the Governor of Curaçao extremely wary; they were also broadly discussed in the spring meeting of the Board of X in 1701. Van Beek's suggestion, to suspend the trade with the mainland, was approved while the governor was admonished to keep a watchful eye over events in the neighboring colony. $48 \mathrm{He}$ was further specifically urged to warn Dutch slavers, passing Curaçao on their way to Cartagena and Porto Bello, of the Spanish attitude. Unfortunately, this order came too late to save three other slavers. $49 \mathrm{~A}$ fourth one, the Vergulde Vrijheid (Gilded Liberty), safely dropped anchor in Willemstad, unloading almost 700 blacks.

For a long time Governor van Beek remained in the dark as to the reason for these Spanish actions. As it turned out, the origin of the trouble centered around the Royal Portuguese African (or Guinea) Company, and its inability to meet its obligations. To avoid possible bankruptcy, the Company - from its headquarters in Cartagena - turned to smuggling. This gave the Governor of Cartagena the necessary pretext for seizing any slaver in employ of the Portuguese Company. As it happened, these were mostly Dutch or English, thus hampering seriously these nations' trade. This muddy situation was cleared up with the so-called Adjustment Treaty concluded between Spain and Portugal in June, 1701.50

But the elimination of this Spanish American market robbed the WIC of many sales and made deep inroads into its profits. The Board of X, thereupon, advised Van Beek to send the blacks instead to St. Eustatius, which seemed ideally situated for trade with the neighboring English and French islands. Van Beek was far from enthusiastic. Besides its lack of money, he protested, the island 'will lie in a danger zone as soon as the war, we are expecting, explodes. Most of its planters have already sent away their sugar, hardware, and slaves to the neutral island of St. Thomas, and are adopting a wait-and-see attitude.' 51

Meanwhile, more slavers continued to arrive. The toerbeurten (the equipment of slavers with cargazoenen - cargoes of commodities - for the African coast) had been organized by the Board of $\mathrm{X}$ a year ahead of time when nothing as yet was known about a 
French asiento. This caused another problem. Now there were 1000 mouths more to feed, a substantial oroblem on Curaçao where almost all food had to be imported. It would mean extra expenses for the Company, unless the blacks were sold immediately. Thus Van Beek - in spite of his recent deplorable experiences with the Spaniards - sent a little barque to the Caracas coast, hoping it would bring back substantial orders. 52 Van Beek's misgivings to the contrary, all the blacks found ready buvers.

Yet worries still nagged at the back of his mind. Rumors, he wrote, circulated in the Caribbean that Portugal was about to loose the asiento and that it would pass into French hands. 'I hope it is not true,' he commented, well aware that this transfer would deal a crushing blow to the slave trade with the French and Spanish colonies. The situation was further aggravated by the constant harassment of lorredraaiers. At the end of February of that same year, for instance, the Caracas coast was visited by a Zeelandian interloper fitted out by the merchanthouse of Belmonte \& Sousa. Belmonte, a Zeelandian businessman, and Sousa, the representative of the Royal Portuguese African Company in Amsterdam, had joined forces and had become partners in a venture to outwit the WIC. The lorredraaier was heavily armed, a dire necessity, because if seized by the WIC, ship and cargo would be confiscated, and captain and crew sent to the United Provinces to stand trial. Its armazoen of 400 blacks, purchased in Angola, was sold in Cartagena. 53

Due to the political climate speculation ran rife among Curaçao's inhabitants. It was hotly debated as to which way the Spanish colonies on the mainland would swing. The Board of X, clearly aware of the dilemma, cautioned the Curaçao governor and told him not to show his hand too soon. Under no condition was he to offend the Spaniards by continuing to issue commissions against them; in case he had already done so, he should recall the privateers. Trade with the Spanish colonies was to carry on as long as possible. Curaçao's very life-blood depended on it. He should keep a careful watch over the Curaçao representatives of the asiento - now that it had changed hands - not trust them, and make an attempt to collect debts still owed to the Company. Rumors had it, the Board concluded, that the French had acquired the asiento which, in view of the fact that the United Provinces had chosen the Austrian side in the emerging conflict, was bad news indeed. 54 
The minutes of the Board of $\mathrm{X}$ reval the varying opinions of the Curaçao governor. While a scant six months earlier, in an exhilarating mood, he had recommended an increase of toerbeurten providing for an annual delivery at Willemstad of 2,500 to 3,000 blacks, he now advised against a possible overextension of available resources. 'In these dubious times the slave trade of this island has come to an almost complete standstill,' he wrote. Buyers were turned away unless they paid in cash. Such was the case of a Frenchman who wanted to purchase 100 blacks; similarly a Spaniard wishing to buy 300 slaves on credit was summarily dismissed. Deep mistrust of both the French and the Spanish, as well as uncertainty about the future, inspired this attitude. 55 In addition, the factors of the asiento in Cartagena delayed payments. 'They act deaf as soon as we attempt to get paid,' Van Beek complained. But the slave trade's demise was not as complete nor as unconditional as the governor made out to the Board. Two months after having written that letter he informed the $\mathrm{X}$ that the existing supply of fit slaves had almost totally been sold. 'If peace really prevails. new armazoenen should be sent,' he advised. 'But the ships should carry larger amounts of blacks.' 56

Peace did not prevail. At the time, Van Beek did not know that Portugal, through some ingenious manoevering on the part of Great Britain, had deserted the Franco-Spanish camp. The Dutch governor, laboring under the assumption that she was still neutral, decided to have slavers carrying their black cargoes to the mainland under Portuguese flags. This plan had to be shelved, however, as soon as it became known which side Portugal was on. 57

In spite of this set-back, the slave trade continued and sales to the mainland coast prospered unabatedly. 'I will do my utmost,' Van Beek had written earlier, 'to sell slaves. I hope that the Almighty grant us a good season.' 58 By now he was informed of the latest developments and was aware that the French had wrestled the asiento from Portugal. New French fortresses were built on the West African coast, and it was rumored that their slavers had already transported more than 1,000 blacks to the West Indies. 59

Peace beyond the line

In Spite of the war, in spite of the change in asiento ownership, the Dutch West India Company continued to trade with the Spanish as if nothing had happened. While there was no peace in Europe between the United Provinces and Spain, there was peace 
'beyond the line.' The Royal Portuguese African Company had closed its offices in Cartagena, the French had taken over and trade continued. Louis XIV may have said that the Pyrenees had stopped to exist, for the Dutch and the French/Spanish asentistas in Cartagena the war did not exist. 60

This beautiful understanding between the enemies was soon undermined by the envious ally of the Dutch. 'The slave trade,' complained Van Beek, 'suffered more from the English, their supposed allies, than from their French and Spanish enemies. 61 The English resented the commercial prowess of the Dutch, and by December, 1702, the Council of Trade and Plantations wrote bitterly that 'the Dutch from Curaçao drive a constant trade with the Spaniards as if there were no war.' 62 The British annoyance led to the accusation that 'they supply the Spaniards as well with ammunition as with provisions,' and concluded: 'We propose that directions may be given to H.M.'s Minister at The Hague to make application to the States General.' 63 Constant reference to this trade which evidently put out the Englishman's eyes, testify the indignation caused by the nefarious Dutch conduct. Such attacks as: 'The Dutch at Curaçao have called in all their Privateers and have free and open trade with the Spaniards far greater than ever,' 64 and 'Open trade of the Dutch with the Spaniards is now greater than in times of peace,' 65 left the Dutch behavior naked before the Council of Trade and Plantations.

The English homilies showed, as usual, certain cockiness. 'It might be worthy your Lordships' consideration about ye conniving at a Trade betwixt our people at Jamaica and the Spaniards... The goods we traffick with are only wearing apparel and Negroes for their mines...' revealed the crucial weakness of Great Britain's jealousy. 66 All this bickering revolved around the fact that the WIC and the Curaçao merchants did legally and with tacit consent of the States General what the English could not. Her Majesty's subjects were officially forbidden - in pursuance of the Declaration of War - to carry on any commerce or private correspondence with the Spanish as they previously had done. The governors of the British islands were under pressure to enforce these orders although they realized too well, that this deprived their colonies of considerable advantages. 'The Dutch have a different regard to their interest,' was their specific complaint. 67

At that time the only way out of the dilemma for the British authorities was to hand out commissions to privateers to seize Dutch merchantmen who were trading with the Spaniards along 
the mainland coast and bring their cargoes to Jamaica. 68 This meant naval warfare between the supposed allies and Governor Van Beek soon felt its pressure. 'The English', he observed, 'threaten to seize everything without any regard of flag or nation.' 69 Moreover, the Dutch not only lost ships but were also threatened with espionage. 'A few days ago an English privateer from Root Island [ Rhode Island] dropped anchor here pretending to keelhaul his ship and to buy food,' wrote Van Beek. 'It seemed to me, however, that his real intention was to seize Curaçao barques trading along the Spanish American coast.' The governor sourly added: 'Trade will not flourish unless the English see a way to profit from it also.' 70 It was another version of what the Duke of Albemarle more bluntly had said four decades earlier: 'What we want is more of the Trade the Dutch now have.' 71 It evoked little consoliation that English privateers in the Leeward group (in Dutch the Bovenwindse Eilanden) also paralyzed all trade with Danish St. Thomas.

The English, of course, tried to disguise their role as a righteous one. The Captain of an English man-of-war wrote to Van Beek: 'I am informed that there are two Dutchmen, one of 36 and the other of 42 guns, lying between Porto Cavallo and Porto Bello trading with the Spanish; being assured that their High Mightinesses, the States of Holland, would not give a commission to any Dutch ship to trade with the enemy, I find myself under the obligation to take notice of it and to warn you that if you cannot suppress it yourself I will direct myself to the English admiral and ask him to send frigates to do the job.' 72

This stout-hearted language exemplified English rectitude but it compounded Van Beek's difficulties to which were added serious clashes with some members of the Curaçao Raad (Council), especially with the slave commissioner Gerard Luls.

In spite of these complications cash and produce from the Spanish American mainland flowed into the island. 73 But fear of an English interference with Dutch trade flared up when rumors circulated that the British fleet had left Jamaica. However, nothing happened and the Dutch governor, again composed, assured the Bord of X that the sale of Piezas de India was going well. His confidence was bolstered by the arrival of a certain Gaspar Martin. This Frenchman from Cartagena, sent by the factor-general of the new French asiento, came to discuss the sale of blacks and their transportation to that port. The agreement between the French and Philip V permitted the asiento authorities to turn to their 
Dutch and English enemies and rivals for aid in furnishing them with slaves that they themselves were unable to provide. 74

Van Beek - and the WIC - had no objections to selling slaves to the French asentistas in Cartagena. He consulted the Curaçao representatives of the asiento for their collaboration in circumventing British vigilance. Their hostility was reaching a peak. As early as March, 1704, they had already seized 21 Dutch ships and barques trading along the mainland coast, and brought them to Jamaica where they were declared good prizes. 75 In view of these difficulties the solution was found in procuring a few Danish passports and sailing the black cargo from Curaçao to Cartagena under the Danish flag. For the time being, this ruse seemed to work. 76

\section{English attitude}

Was Van Beek really unaware of the contradictory policy of his country - a policy in which the States General unofficially backed the WIC - in fighting the French and Spanish in Europe while trading with them in the Caribbean? Although the English attitude demonstrated a curious blend of righteousness and hypocrisy, the Curaçao governor's letters show an ignorance of elementary principles which - feigned or not - bordered on insolence. 77

Undoubtedly, the English threat to Dutch trade was a serious one. If Van Beek wrote humorlessly that they were many times unsuccessful in seizing Dutch traders, there was no denial of mounting tensions between the two allies and regular small-scale naval battles were fought in the area between the Curaçao islands and the mainland coast. The Curaçao governor, thus, found himself in the line of two fires. From one side the English were doing their upmost to discredit and disrupt the Dutch trade with the enemy, while on the other side the Board of X and the Chamber of Amsterdam of the WIC were sending secret orders to encourage the trade with the Spaniards. The prohibition of the Board to hand out letters of commission against the Spanish proves this point. Trade should continue, no matter under what political circumstances.

Confronted with this problem but determined to keep the trade going, the Curaçao governor introduced a 5,000 guilder security premium for the traders. It was a guarantee against any hostile Dutch action with regard to the Spaniards, thus avoiding any incentive for reciprocal enmity. Peace beyond the line was the Dutch policy. Van Beek was assured that this high premium 
would steer the Dutch clear of any conflict with their business partners and not ruin the Board of X's good intentions. 'My experience in granting letters of marque,' he wrote, 'has taught me that only this amount of premium will stop merchants and sailors exporting ammunition and other war material to the enemy under the pretext of fair trade.' 78 Nevertheless, he seemed perplexed by the peculiar situation his island was in. 'I find myself in an extremely difficult position,' he complained. 'At one side we are burdened by the complaints of our merchants that they are ruined and robbed of their profits without getting any satisfaction; at the other side I can not see that the English are completely wrong, more so because official placards - sent to me by the Chamber of Amsterdam - forbid the export of all merchandise to the enemy and the import of all French and Spanish produce. As long as the English are not profiting from the situation they will stubbornly try to stop our trade.' 79 The perplexed governor, therefore, asked explicit orders.

The English position was, of course, a much clearer one. In answer to a request by Governor van Beek to send back three Dutch barques taken by an English privateer, Lt.Governor Handasyde of Jamaica, a firm and honest representative of the English Crown who did not associate with any piratical acts, replied: 'I thought that the declaration of War a year ago by both the English and the Dutch against the French and the Spanish and their High Mightinesses' placards forbidding all manner of trade and commerce ... had been notice and caution enough. Eight months ago... I told you if you would not stop these proceedings I would be obliged to write to England about it ... your sloops and goods are here condemned by H.M.'s Court of Admiralty to the Crown I serve and my honour obliges me to detect such underhand practices.' 80

Did this clear language dissolve Van Beek's perplexities? Despite efforts to please both sides, the Board of X was dissatisfied with the way he handled the complex situation. Moreover, his inefficient bookkeeping and the constant quarrels with his subalterns and the Raad gave the Board of X sufficient reason to accuse him of fraud and corrupt dealings. He was discharged of his office in 1704; his premonition of this action was evidenced by several requests for dismissal. He was replaced by Jacob Beck who after a long and dangerous voyage, arrived on the island at the end of August of that same year. 81 


\section{Effects of English privateering}

The change in governor did not influence the effects of English privateering. One of their privateers, Reynier van Tongerloo, a Dutchman with an English commission from Jamaica, had seized no less than eight Dutch vessels trading along the New Granadian coast and the Caracas area. Another Dutchman, Adriaan Claver, with a commission signed by Governor Van Beek, had turned against his countrymen, seized a richly laden Dutch barque at Porto Bello, sunk it and carried its cargo to Jamaica. 'It will be highly necessary,' the new Curaçao governor wrote, 'to safeguard ourselves as much as prossible from our friends and allies the English.' 82 He should have added: 'And from our landsmen.' His request to the Jamaica governor to stop any commissions against Dutch trade was denied. 'The procedure by which patents and commissions were granted,' the answer said, 'was exceedingly intricate and cumbersome. Each step in the complicated and varied processes was marked by a document of a particular form,' which meant, in simple language, that the English were unwilling to cooperate. 83

\section{Change in the English attitude}

Fortunately, a new load of blacks, arriving with the Vrientschap from Elmina in August of that same year, 1704, enabled some profitable sales with the Spaniards, which made the future look less bleak. Because of the problems involved in the transportation of those Piezas de India to Cartagena, the new governor, rather innocently, tried to persuade the Jamaica authorities not to interfere. He even wrote to the admiral of the English fleet there. 84

These requests illustrate vividly the decline of Dutch power in the Caribbean. Even the States General were unable - or unwilling - to protect Dutch transatlantic navigation. Merchants' requests for armed protection directed to the Admiralty Board of Amsterdam and to the Provincial States of Holland and West Friesland were not granted.85 There were no men-of-war available.

Well aware of their strength the English by means of a careful balance of privateering and open hostility executed their control of the Caribbean. The Dutch could hardly vindicate their position. The Curaçao merchants, quick to scrutinize the unfavorable situation, directed themselves to the Raad, which was powerless. 
Unable to improve the situation, a group of these merchants finally decided to pay the abovementioned Van Tongerloo 8,000 pesos (20,000 guilders) for a written promise not to molest their ships. The three representatives of the asiento, questioning strongly the value of such a promise, did not contribute to this ransom. Ironically, these Ps.8,000 seemed to have originated from the seizure of a Dutch barque, the Comercio, seized by Van Tongerloo, but whose cargo had been graciously returned to their owners. 86

But the darkest hour heralds the dawn. That crooked governor but fine psychologist, Nicolaas van Beek, had sounded the English mind fairly well. 'Trade will not flourish until the English see a way to profit from it also,' he had written at an earlier date. 87 The Council of Trade and Plantations was fully aware of the disadvantages for the English colonies if there were a complete break in trade relations with the Spanish enemy. In October, 1703, it wrote to the Queen regarding the Dutch position, and 'the great discouragement Her Majesty's subjects in the West Indies and the home country experienced because of the prohibition.' $88 \mathrm{~A}$ circular letter, entitled Reasons Against Probibiting Trade and Commerce with Spain in the West Indies made it clear that 'such prohibition of commerce with the Spaniards would be no less prejudicial to Great Britain... That will debar us from vending our native commodities to them for pieces of eight or other valuable goods... it will throw our part of the Spanish trade into the hands of the Dutch who have several Plantations near the Spanish coast, that although they may have a formal direction of the States General on whom it is well known, they have little dependence when the interest of Trade prevails in parts so remote as the West Indies.' 89 Thus, the tide was beginning to turn.

In answer to protests made in The Hague by the British envoy, the States General presented the Queen with a memorandum pointing out the reasons why the Dutch were allowed to trade with the Spanish.90 The Queen, upon consideration of the English and Dutch position, thereupon changed her attitude. By now she thought fit 'to continue the trade and commerce with the Spaniards in those parts during the war, in all commodities excepting stores of war and ammunition and such commodities as are prohibited by law to be carryed from Her Majesty's Plantations directly to any foreign country.' 91 The English were now permitted to carry on this trade and orders were given not to molest 'any of the Dutch in their trade', except in the case of carry- 
ing stores or ammunition of war. They were admonished to take care 'that the French receive no benefit of this indulgence.' 92

As a result of this order all hostillities with the Spaniards in America were ceased. The position of the Dutch was now looked up to and their policy practised. The Additional Instruction to Prvateers shows the enormous change in attitude adopted by the English. 'Whereas we in conjunction with our allies the States General are willing to encourage our and their intercourse with such of the Spanish Nation as shall be inclined to acknowledge the title and sovereignty of Charles III, King of Spain, with whom we are in friendship and alliance.' At this point the chances of the Archduke to the Spanish throne seemed excellent, causing Louis $\mathrm{XIV}$ to fear that Charles would rally the Spaniards to his support. The moment seemed opportune to follow less rigid regulations. 93

This sensational turnaround of Great Britain's trade policy in the West Indies posed no problem for her governors who were well aware of the damages caused by the former attitude. Even that vociferous critic of the Dutch, Governor Thomas Handasyde, 94 could soon write triumphantly: 'Several of our trading sloops have already been trading with the Spaniards... they might have an extra-ordinary trade.' 95 This signaled the end of the English harassment of Dutch trade along the mainland coast. Now, although the Dutch got rid of the British privateering nuisance, they gained a powerful competitor.

\section{The French challenge}

The new English role opened a second phase in the Caribbean, that of the French challenge. In the three years that followed, French privateers delivered several blows to the West India Company bringing it almost to the brim of bankruptcy.

Few slavers had dropped anchor in Curaçao during the years of the English obstruction, but at the end of 1704 two safely arrived at Willemstad, followed in the beginning of 1705 by a third one. The demand for slaves was great and could not even be satisfied with 2,000 more blacks, especially if they originated from Ardra. These were particularly in demand.

Encouraged by these profitable prospects the Curacao governor tried to convince the board of $\mathrm{X}$ to fit out more toerbeurten. Not yet knowing the real reason for the diminishing English raids on Dutch shipping, he attributed their less aggressive attitude to the safeguards he had taken to protect his island's trade. These con- 
sisted of specially equipped cruisers for the purpose of shielding the business relations with the Spanish American mainland. In order to finance this measure Beck created a special fund, the socalled kaapvaartkas (privateering fund), by raising a special duty of 1 percent on all imports with the explicit object to pay for the extra expenses. Not only were the imports from the mother country taxed but also the merchandise brought into the island by Dutch, English, or other privateers. 96

This fund seemed to fulfill its purpose. Although the end of English privateering on the Dutch was not a result of the activities of the Dutch cruisers equipped by the kaapvaartkas, they certainly limited French aggression and performed well even seizing French corsairs 'with vigor and valor' bringing them to Willemstad. Somewhat later, in 1706, the Admiralty Board of Amsterdam, which previously had refused all help, probably realizing the seriousness of the French threat, now declared itself willing to give convoy to the ships of the WIC and the Caribbean navigators with two men-of-war twice a year. For this service it asked $2 \frac{1}{2}$ percent as incoming and 3 percent as outgoing duties on cargoes destined for or leaving the Dutch port. 97 In 1707, a first convoy arrived at Curaçao protected by two men-of-war, and since that year up till the 20th century, with only a few interruptions, Curaçao's port always harbored these so-called station-ships.

At the end of 1705 more slavers arrived. Around that time Governor Beck also received orders to raise the price of the Piezas de India from 100 to 108 pesos. The Board had two reasons for this raise. The blacks at Fida became increasingly scarce, while also the great demand of the Spanish mainland colonies lured the Board away from the lower price. However, both Governor Beck and slave commissioner Luls were concerned that this would turn prospective buyers to Jamaica and St. Thomas where slaves, it was rumored, could be obtained at prices as low as 80 of 90 pesos a Pieza de India. Furthermore, the buyer in Curaçao who paid in coined gold or silver would really pay 115 instead of 108 pesos, due to the scarcity of cash which raised its value around 7 percent. Aware of this danger, the Board of $\mathrm{X}$ authorized the governor to sell the blacks, if necessary at the more convenient price of 106 pesos, suggesting also a public sale for the Piezas de India. 98

Governor Beck, already opposed to a raise in price, pointed out that a public auction of the Piezas de India would be effective only when there was a small quality of superior blacks and plenty of buyers. Besides having no high quality slaves the buyers were 
mostly Spaniards, the English and French islands being closed to Dutch trade. Those Spaniards, Beck wrote with typical nordic phlegm, were not easy to deal with. Being used to a certain way of trading they would be disinclined to adapt other methods. He was sure they would refuse to appear at public sales. 99

In 1706, several slavers having miraculously escaped the threat of French privateering in an expanding war dropped anchor at Willemstad. Although the price of blacks had gone up considerably, they were sold immediately, Piezas de India, mancquerons, and sick slaves.

Besides the French privateers and the interlopers or lorredraaiers who hampered the WIC slave trade, the governor was faced with another irritating though small problem. Many captains of the Company's slavers constantly tried to smuggle one or two blacks into Curaçao on the pretext that they had received them as a present from the negro ruler back in Africa. The WIC repeatedly gave strict orders to confiscate those blacks and sell them for the Company. The captain of the Son, for instance, in a request to Governor Beck, tried to keep two slaves, claiming them, as usual, as a present. He failed and the two youngsters were confiscated and added to the ship's armazoen .99

\section{More confusion}

While at that time the Allied forces made excellent progress in Europe and the chances of the Archduke Charles of Austria to mount the Spanish throne seemed better than ever, the situation in the Caribbean became considerably more confused. The Governor of Curaçao was ordered not to hand out any commission against the Carlista Spanish, but to confiscate all Spanish ships with a commission signed by Philip, considered 'enemies of the United Provinces.' 100 At the same time the aggravation of the war caused the WIC heavy losses which dealt severe blows against its financial stability. Several slavers never arrived, seized or sunk by the French. No dividend was paid in 1705 and 1706, but in 1707 the Board of $\mathrm{X}$, after much hesitation finally decided to have a uitdelinghe (dividend), not paid, however, in cash but in additional stocks amounting to 5 percent of the investment. In face of the severe setbacks of the Company, this decision probably was an effort to stimulate the investors' morale and to gain support from the government in its difficult plight. 101

By the close of 1707 and at the beginning of 1708 more slavers brought relief, sometimes unloading blacks from the African 
coast, the less desirable ones. Nevertheless, they were all immediately sold, again reflecting the pressing demand. 102

As a result of the scarcity of commodities and blacks some peculiar consequences developed. All European colonies, laced in a set of rules and regulations, were forbidden any inter-colonial trade. Now, however, with the irregularity of supplies from their mother countries contraband activities flourished. Governors and other officials of the British islands, for instance, admitted that their own people were involved as heavily as the Dutch in smug. gling. This complaint became a topic in the correspondence between the English officials and the Council of Trade and Plantations. 'Curaçao is never without Bermuda vessels,' wrote Lt.Governor Bennett. Another letter gives many details about the illegal trade between Jamaica, Curaçao, and St. Thomas. 103 In vain governors and proprietors were admonished to take all precautions to discharge it.

Could it be that the English colonies suffered more from the effects of the war than the Dutch or the French? Governor Handasyde of Jamaica often complained about 'the deadness of our trade to the Spanish coast.' 104 This deadness seemed also to have reached Barbados. In September, 1708, some merchants from this island, who had their eyes on the future, petitioned the Queen to promote the trade with the Spanish West Indies through acquisition of the asiento which 'may be of such advantage to this Kingdom and to Your Majesty's Plantations.' 105 Indeed, being excluded from this profitable business made it easier for Great Britain to dress herself in a cloak of honesty and morality. But English jealousy was minute compared to previous years, and thus the Curaçao governor and the WIC were not overly concerned. They were faced with another complication which opened another era in the Curaçao slave trade. This was French willingness to open official trade relations, a proposition which caused some embarassment and much caution.

\section{The Chourio episode}

Late in 1707 , the Chamber of Amsterdam received a curious request from two Jewish merchants, the brothers Louis and Jean Mendes da Costa, for permission to conclude a contract with the French Company of Saint Domingue for the delivery of three or four shiploads of blacks. They offered a cash sum of 30,000 guilders for each shipload (12,000 pesos) while the remaining 30,000 guilders would be paid in commodities and merchandise upon 
delivery. 106 The Board of $\mathrm{X}$, somewhat put out by this request, postponed a decision to its next meeting. The petition was then denied.

More serious contact was made in early 1708. Arriving from La Guaira, a certain Monsieur Chourio asked for an audience with the Curaçao governor. He was - as Luls, the slave commissioner, commented - the son of the Spanish consul at Amsterdam and had lived in Martinique, before representing the French asiento of Cartagena. Beck, somewhat distrustful, requested that two members of the Raad be present. 107

Chourio, showing the Dutch officials his commission as asentista for Trinidad, Margarita, Cumaná, and Maracaibo, allegedly signed by Philip V, told them that it granted him the right to buy slaves for these colonies in Jamaica as well as in Curaçao. As already observed, the French asiento did indeed contain a clause permitting these dealings with the enemy. The Frenchman went even further to reveal the unique possibilities of the asiento agreement. It could be extremely profitable and feasible, he explained, to include other commodities in their commercial relationship. The Spanish colonial mainland was in dire need of many things. Therefore, he proposed direct and regular communication between Curaçao and Venezuela. The mainland would pay in cash and produce for blacks and other merchandise. There was, however, a catch to his offer. It would be necessary for Chourio to establish residency on the island and open an office there. 108 The number of blacks needed could easily amount to 1000 Piezas de India yearly. The question concerning the transportation of these goods and blacks to the Spanish mainland was easily solved, although both parties realized that the English would be very watchful. His licence, Chourio assured Beck, required that each ship should be manned with at least half French crews. 109

Regular visits of French and Spanish sailors would, of course, create a dangerous possibility for espionage and treason. After all, a war was going on. Who would be able to tell if a sailor was not a spy in disguise? The feelings of the Raad, called together to discuss this extra-ordinary proposal, were far from unanimous. No option was barred from discussion, however, not even that of French sailors being admitted in Willemstad's port. While the Raad deliberated, Chourio, proving that he meant business, bought enough merchandise, partly on credit, to send a sloop to Maracaibo. Governor Beck, moving effectively to counteract any 
efforts against the French asentista, sold him 65 inferior blacks for the full price of 108 pesos a piece. At long last the Raad granted the Frenchman a temporary permit to stay depending on the final approval of the Board of X.110

Now the Curaçao governor was in bad need of armazoenen. Luckily, at the end of 1708, two slavers dropped anchor at Willemstad unloading almost 650 blacks. Chourio bought more than 200 at the regular price of 108 pesos. He paid in cash and cacao. 111 Another French buyer, from Saint Domingue, also bought a number of blacks.

The successful arrival of these two slavers was dampened by the disappearance of a third one, seized by the French privateers almost in sight of Curaçao.

\section{The Raad and Chourio}

At the end of 1708, Governor Beck asked for his dismissal, and was replaced by his brother Abraham Beck. Jeremias van Collen, the commissioner of train en vivres (material and vivres), who had acted as temporary governor after Van Beek's dismissal now again functioned as such. When Abraham Beck died in October, 1710, Van Collen became acting governor for the third time. Descendent of a well known Amsterdam regent family, very influential in the affairs of the WIC, he was in spite of this background overlooked two times for the highest position of the island. Finally, after his third acting governorship the Board appointed him governor on December 17, 1711. He served as such until his death in January, 1715.112

Van Collen had been strongly in favor of Chourio's proposals but his hands were tied. He had to wait for the decision of the Board of X. It came at the end of May, 1709, while he was still acting governor, and took half a year to reach his hands, eloquently illustrating the slow rhythm of communication of those days. To the great astonishment of the acting governor and the majority of the Raad, it contained strict orders to forbid Chourio or his staff to reside on the island. Should they already have established an office there, he and his aids should be arrested, sent back to the mainland, and their belongings in commodities, blacks, and cash be confiscated. 113

The Raad member Laurentius Horst, a medical doctor, had already very outspokenly demonstrated his anti-French feelings. Clearly, he said, the French were planning to spy on Dutch shipping. The admission, according to Horst, of 'mortal enemies of 
the United Provinces' could only cause commotion, detriment, and disaster. 114 Nevertheless, his voice was not heeded until the French had seized the WIC slaver St. Jago just as it entered Curaçao's port. Indignant and upset, the Curaçao merchants then accused Chourio and his staff of having been instrumental in this seizure with their espionage.

The decision of the Board was not inspired by a lofty effort to curb the trade with the enemy. Shortly later, during Abraham Beck's term, the Board issued specific orders to continue the trade with the mainland and to treat the Spaniards with 'civility.'115 An additional recommendation approved the admission of Spanish ships in Curaçao's port bringing their produce in exchange for slaves. 116 Torn between lust for profit and fear of treason the $\mathrm{Cu}$ raçao governor was not always sure which course to follow. But the continuous losses of Dutch navigation in the Carribbean, as well as on the African coast, clearly proved the existence of informers. At that time, in 1709, around 150 Frenchmen of various professions lived in Curaçao. 117

Chourio was in Venezuela at the time the Board's order for his arrest had arrived. Pending his return his property was seized: a barque La Royale with 40 blacks, another one, La Diligence, and a bergantine, Le Postillon, with 25 Piezas de India. Fifty Piezas de India, purchased but not yet delivered and residing on the WIC plantation Rooy Canario, were also confiscated. Furthermore, 30 mancquerons and sick slaves kept on the plantation of Gerard Luls - probably his reason to permit Chourio on the island were taken into custody. 118

Chourio, it soon appeared, was deep in debt most of which he owed to the WIC which claimed 15,000 pesos, while he owed another 10,000 pesos to various merchants. Upon his arrival in Curaçao, soon afterwards, he was arrested together with his staff of 32 members. The arrest was a mild one, the Frenchman being confined to his quarters in Punda (the walled-in section of Willemstad). He declared himself innocent of the charge of espionage and repeated this in a session of the Raad to which he was invited.

His high debts made it impractical to extradite him immediately. After long deliberations the Raad finally admitted the Frenchman again, in flagrant contradiction of the Board's orders. He endeared himself even more to the commercial interests of the island by buying 330 Piezas de India from the Company at the 
fixed price, and commodities from many Curaçao merchants amounting to 40,000 pesos, claiming that he would have bought much more had he not suffered huge losses in Maracaibo where the authorities had confiscated 50,000 pesos worth of property. 119

Van Collen's interpretation of the Board's orders was a peculiar one, but a majority of the Raad supported his views: arrested, Chourio would be paralyzed and never be able to pay his debts. The prosperity of the Company and many island merchants was at stake. When Abraham Beck arrived and was confronted with this situation, he accepted the official position. It was taken, he wrote the Board, to give all Chourio's creditors an opportunity to hand in their claims, to give the Frenchman an opportunity to do business and pay his debts, and to gather more information about his involvement in the seizure of the St. Jago and several other Dutch ships. 120

With the adhesion of the Raad the French thus were absolved of any misdemeanors, treason, or damaging correspondence. Both Van Collen - who even issued a Declaration to this effect and Abraham Beck had the support of some Curaçao merchants, in particular of the Curaçao asentistas. One of them, David Senior, was even willing to pay a guarantee of 5,000 pesos in cash or bonds (bodemerij brieven) in order to permit Chourio to export 70 blacks to Maracaibo, offering as security his house in the Jodenkerkstraat (Punda), together with 20 slaves. 121

But not all Curaçao merchants shared this point of view as proven by a request of many businessmen protesting the admission of Spanish ships (among them Chourio's of the French asiento) into Willemstad's port. The Spanish had been doing this freely ever since the English acquiesced to the Dutch-Spanish trade. By now, however, these merchants were getting second thoughts and realized the detrimental effects this admission had on their own business. The Spanish brought produce from the mainland at competitive prices, and as a result the governor was now petitioned for restrictions of this free entry. 122

Since Governor Beck was making an inspection tour to Bonaire, Van Collen presided over the meeting of the Raad in which this request was discussed together with Chourio's protest against the confiscation of his barques. Taking an opposite view from earlier debates he now urged the Raad not to grant Chourio any favors, to sell all his property in public auction so that his debt to the Company could be settled. Then he should be extradited. 
This attitude only took into account the interests of the WIC and disregarded Chourio's involvement with the Curaçao merchants. The slave trade commissioner Luls took their side. The Raad - in which some merchants had seats - agreed with Luls and permitted the Postillon to sell its blacks and other commodities in Maracaibo. This decision had the strong approval of all of Chourio's creditors who supported Luls' attitude and the decision of the Raad 'so that he will be able to pay us.' 123

The following balance sheet makes the importance of the Raad's decision obvious. It shows the involvement of some prominent Curaçao merchants and the commodities of Chourio's transactions: 124

\section{CHOURIO \& CHAMBERT}

DEBENT

Schuurman en Moyaert
David and Isaac Senior
Mord.de Castro
Idem persatilo
Ferro and Nara
Manuel Alvares Correo
Eli Gilbert
Joan de Nis
De Ede Comp.
Brandau and Bundes
David Lopes Dias
Freeze \& Otto
David Senior of the security

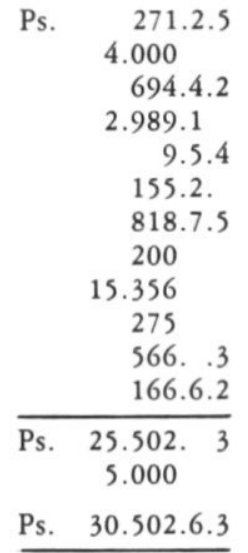

CREDUNT

For a bar gold in cash in custody of the governor For security of Dd Senior

For 60.00011 cassave

For barrels of indigo

For 2 barques (Postillon and Royale)

For 34 blacks

For Flemish striped linen

For 108 barrels flour

Ps. 1.748 .6

5.000

7.200

250

2.400

3.400

350

800

For the auctioneer

271

For Jacob Kamp

1.636

For Jeronimo Juyst

100

Compt. per saldo of this a shortage of

Ps. 23.155 .6

$\begin{array}{r}7.347 \cdot .3 \\ \hline \text { Ps. } 30.502 .6 .3\end{array}$ 
A similar procedure was followed regarding Nicolas Gautier, the Frenchman from Saint Domingue, whose debts to the Company amounted to 4212 pesos. His property was also seized after it had become apparant that information about Dutch shipping was leaked to some privateers cruising around Hispaniola. As in the days of the English harassments, the kaapvaartkas was again used for the equipment of several armed barques for surveillance and protection. 125

The Curaçao merchants, in the meantime, still apprehensive, requested to postpone the sailing date of a convoy waiting in St. Ann Bay. Sure enough, at the end of 1709 , news came that the French had taken St. Eustatius and were cruising between Mona and Puerto Rico waiting for a Curaçao convoy. 126

Undisturbed by these rumors, Chourio offered to buy 1500 blacks if the Raad would permit one of his barques into Willemstad's port. Strong opposition denied this request and Chourio was ordered to pay his creditors and leave the island at first notice. But the astute Frenchman, never at the end of his wits, asked for a hearing and his appearance in the Raad worked wonders. He assured the members that his three barques - if set free - would return from the mainland loaded with food. Because of an extremely dry season and the threatening scarcity of victuals the Raad, albeit reluctantly, granted the request in spite of strong protest from many Curaçao merchants. The latter were loosing ship after ship and were far from happy. 127

Although there does not appear to be enough concrete basis for the imputations of the merchants, it is questionable of Governor Beck followed a wise course in granting Chourio his request. There was no guarantee that his crews would not sail straight to Martinique or inform the French privateers swarming around the island of Dutch shipping schedules. The food situation was, however, extremely pressing. Food was the island's Achilles heel. Its desertlike climate did not promote agriculture. Beck had already bought 10,000 bushel of corn after cattle started to die. Everyone knew that the slaves were next in line to feel the squeeze of food scarcity: break-ins and burglary, mainly in search of food, became daily occurrences. In August, 1710, a long trial against two of the most notorious thieves triggered more unrest. Both were convicted and hanged. The slave population manifested open hostility, and the placards issued by a frightened governor reflected the growing official concern. 128 


\section{Collapsing prosperity}

In the midst of these tensions the war situation worsened. The threat of the French enemy and the English ally increased. A French corsair, for instance, seized 27 blacks on Bonaire without meeting any resistance. They captured also the slaver Amsterdam on its way from Fida to Curaçao. Its captain had given up only after a gallant fight of three hours. Beck advised the Board to send new instructions to the Caribbean navigators that they should not enter this dangerous area south of Tobago. His advice was heeded. 129

Great losses in slavers and other ships intensified the economic and political squeeze Curaçao was experimenting. Not before September 1710, did the first armazoen of that year arrive. Nothing was known of the slaver Moscow nor of the Africa. The heavy losses were only partially compensated by the arrival of the Carolus Secundus but this slaver arrived in a completely desolate condition, damaged to such a degree that Governor Beck set 10,000 pesos aside for immediate repairs. 130

The collapsing prosperity of the island forced the Curaçao merchants once again to request the governor to put a close watch on all foreigners, espectially the French. Freedom of movement for them clearly appeared to be unwise, dangerous, and unrealistic. Refraining from direct accusations the merchants again hinted that information had been given out about Dutch shipping schedules. 131

Naturally, the governor and the Raad were sincerely concerned about these complaints. But trade was declining rapidly, and more obstacles in its way would result in more deterioration. Unwilling to remain passive, Chourio had the audacity to reappear unexpectedly in the midst of this crisis, and proposed a new deal for the delivery of blacks. If his suggestions were accepted, he assured the governor, he would take care of the transportation by using ships under Dutch or Spanish flags, and he would not reside on the island. 132

Acting Governor Van Collen, again revising his former attitude and strongly inclined to improve the bad economic situation, attempted to persuade the Raad to restore the broken relationship with the French. A majority of votes finally decided in favor of Chourio's proposals, depending, of course, on the final approval 
of the Board. He was, however, not allowed to settle on the island. Consequently, Chourio, renting a brigantine from Philip Henriques, one of the Curaçao representatives of the French asiento, sailed to Coro under the Dutch flag returning a few days later with 40,000 pesos in cash. Boasting that he could use 3000 blacks, he arranged his affairs with the island's firm Freeze \& Otto which committed itself to the delivery of 400 Piezas de India and received Chourio's power of attorney, while the Frenchman deposited 6000 pesos as a down payment. The remaining 34,000 were spent on purchases from many Curaçao merchants. In this way the cunning Frenchman endeared himself to the merchants and involved himself strongly in the island's economy. But hostility flared again when several French stowaways were discovered in the ship that had brought Chourio to Curaçao. The Raad members Rudolphus Horst and Pieter de Senilh captain lieutenant of the island's militia, openly voiced their mistrust and suspicion. 133

\section{More difficulties for Curaçao}

In the summer of that same year 1711 Curaçao was again faced with a critical food shortage. Moreover, Van Collen learned that the French were making preparations for an offensive against $\mathrm{Cu}$ raçao. Luckily, the year passed without a French attack but no slavers arrived either except for one. Business with Chourio fell flat. Only the leftover blacks from previous armazoenen were for sale. Forty were finally sold in exchange for cacao and sent to Maracaibo.

As governors before him, Van Collen threw much of the blame for the island's declining trade on the activity of French and English privateers. They found, he wrote, a worthy ally in 'a monstrous governor' of the Caracas area, who 'was in the service of Philip V, a descendant of the Moors, very cruel and malicious' who had already killed more than 20 merchants accused of trading with the Dutch. 135

At the end of April, 1712, the first slaver in almost a year and a half, arrived in Willemstad, gladly welcomed with its 570 blacks of which Chourio purchased 358. By now the sale of 'living ebony' had become, for a great part, dependent on the French of the mainland coast and Saint Domingue. Chourio, well aware of this situation, showed himself no longer very pliable and requested the circumvention of recently set rules, threatening to buy his blacks in St. Thomas or Jamaica if the Company did not comply. 
The Board, for instance, had again ordered to sell all blacks, also the Piezas de India, in public auction, and Chourio refused to bid. The governor was in a bind between the orders of the Board and the Frenchman's adamant attitude. He consulted the new slave trade commissioner, Willem de $\mathrm{Bij}$, the successor of Luls who had died, and decided to bend the new rules a little. The Board later approved his decision. 136

Such difficulties, if hardly conducive to excessive optimism, were minor irritants at best. The attack of Jacques Cassard in February, 1713, made a much deeper impact. It led to the payment of a ransom of 115,000 pesos 'in cash, commodities, and slaves.' Fortunately, the blacks of two slavers, which had arrived before this disaster, had already been sold, thus limiting the share of the Company in this ransom to 12,000 pesos. While the islanders and the new slave trade commissioner hopefully waited for the arrival of new slavers to recuperate from the heavy blow the French had delivered, news arrived that the first one expected had been wrecked. 137

\section{The English Asiento}

The Peace of Utrecht, concluded in 1713, filled the Board of X with high hopes for a revival of the slave trade. The asiento agreement - rumors said - was not yet firmly settled, and existing Dutch suspicions of deceitful tactics of the ally had not yet assumed a profile of certainty. Somewhat naively, the Board expected the profits of the slave trade to be just around the corner. At Curaçao, the arrival of the slaver St. Marcus, in January, 1714, seemed to affirm those blissful expectations. Chourio purchased 511 of its armazoen of 556 surviving blacks, eloquent proof how much Curaçao now depended on the trade with the French. Highly optimistic, Chourio also made claims on the next armazoen. Little did he know that France, for peace's sake, might sacrifice the asiento and grant it to the English. The Board of the WIC worked under the same false assumptions. By the time the next slaver, the Coninginne Hester (Queen Esther) dropped anchor in Willemstad, a dramatic change in the slave trade had taken place.

Despite the alarming rumors of an English asiento, Governor Van Collen refused to see the handwriting on the wall, and was equally eloquent to denounce the disastrous consequences which a possible loss of the slave trade would carry for the Company. Living under the preposterous assumption that profits still could 
be reaped from sales to Cartagena, the Porto Bello region and the Caracas coast, he could not see the cold reality of the facts. The Dutch, he believed, could still control much of the trade; they still had a strong position on Africa's West coast, and an excellent market in the regions mentioned. Strengthening the island's defense system would maintain this grasp on the slaving business. 138

The commissioner of the slave trade, De Bij, did not suffer from such grave misconceptions. The slave trade in the Guianas, Leeward-, Windward Islands, and Hispaniola had fallen under the control of the English, he wrote, while the mainland coast had become the scene of a losing struggle between the interlopers of many nations. He expressed considerable concern, and the arrival of the Conginne Hester with a very pityful armazoen did not improve his views. Chourio, well aware that the asiento was slipping away from him, bought only 88 blacks which were sent to La Guaira where only 17 were sold. The French were finished and Chourio knew it. He brought the depressing news to Curacao that the official installation of the English representative of the asiento would be only a matter of time. 159 It also rung the deathbell for the Curaçao slave trade.

Because of the great distance between the mother country and the Curaçao colony, the subsequent slowness of communication, and the organization of toerbeurten a year ahead of time, slavers continued to arrive. The Board of X had equipped at least seven slavers for the year 1715. Only four arrived at Curaçao, the fate of the other three remaining a mystery. These four brought over 1000 blacks, but Chourio had left, and the new asentistas along the coast did not want to get involved in trade with the Dutch. The Curaçao slave trade commissioner wrote in July, 1715: 'I must tell your Lordships to my deep sorrow that we don't have any buyers for them.' 140

Over 1000 extra blacks to feed this distressing situation on the desert island was contributed by the Curaçao officials mainly to the English. True, the interlopers had increased their activity and sold their blacks cheaper, but the English added, as De Bij wrote, insult to injury by allowing the Spaniards to use English flags to seize all Dutch traders along the coast. 141

The Peace of Utrecht meant an English victory in the Caribbean, not so much over the French enemy as over the Dutch ally: the disastrous end for the Dutch of another Anglo-Dutch war. The ruin of the WIC now seemed imminent. What could be done 
to avoid it? Van Collen died in January, 1715, thus escaping the misery of a demoralizing catastrophe. The English had the men, the ships, the power, and the arrogance. After a century of warring against the Dutch, they had finally finished them, and would soon embark on their next goal: the elimination of French competition. The Dutch, with the Peace of Utrecht, after having been a worldpower for almost a century, became provincial and second rate.

Van Collen nor the slave trade commissioner De Bii had the answers to the company's problems. They were at loss. Did the Board of X know a solution? It was fully aware of the deteriorating state of affairs but did it have a clear insight in its causes? At the beginning of the war, in its session of November 13,1702, it had stated that 'the slave trade has always been considered the leading trade of the Company'.142 In its session of December 5, 1711 , extremely troubled about the fate of the Company, its members listened to a memorandum of one of the directors, Cornelis Bors van Waveren representing the Chamber of Amsterdam, who 'with regard to the critical constitution of the Chartered West India Company of these countries' proposed a reorganisation. Van Waveren attributed the Company's decline to various causes: the war, the English role in their competition with the Dutch, but principally the inefficient internal organization which he considered to be obsolete. 'In the multitude of Chambers consists all mischief,' were his words. Consequently, he suggested the elimination of the Board of X and all the Company's chambers, except the Amsterdam one, which owned alreadv 4/9 of the capital. The liquidated chambers would be integrated in the Amsterdam chamber which, thus, would acquire a broader basis. A new presidium of ten directors would head this chamber, four representing Amsterdam, two Zeeland, and one member for each of the other liquidated chambers. A tenth member would rotate between several provinces and cities. The immediate savings in overhead, Bors van Waveren concluded, amounted to at least $f 40,000$ yearly. 145

Naturally, this proposal irritated the Zeelandian members of the Board of X. In another meeting, two years later, they reacted correspondingly. In stead of a reorganization a merger with the prosperous Dutch East India Company was proposed. Eloquently, the advantages of such a merger were brought to the attention of the Board. 144

As usual no decision was reached and the Company tottered 
forward into a dark future without any sense of direction or goal. 145

It seems correct to conclude that after 1716 the slave trade of the WIC went definitely downhill. The War of the Spanish Succession and the English Asiento delivered the death blow.

\section{NOTES}

CSP $=$ Calendar of State Papers. NWIC $=$ Nieuwe West-Indische Compagnie. CTP $=$ Council of Trade and Plantations.

1. Frank Taylor, The Wars of Marlborough, 1702-1709, Oxford, Basil Blackwell, 1921, 2 vols., I 83

2. Elizabeth Donnan, Documents Illustrative of the History of the Slave Trade to America, Washington, Carnegie Institution, 1931, 4 vols., II, xiii.

3. Taylor, I, p. 57.

4. John E. Emerich, First Baron Acton, Lectures on Modern History, London, MacMillan and Co. Ltd., 1906, p. 252.

5. Frances Gardiner Davonport, ed. European Treaties Bearing on the History of the United States and its Dependencies, Washington, Carnegie Institution, vol. III, 1934, p. 29.

6. Ibid., p. 51 .

7. Georges Scelle, La Traite négrière aux Indes de Castile, Paris, L. Larose, L. Tenin, 1906, 2 vols., II, 97.

8. Jonathan Swift, The History of the Four Last Years of the Queen in The Prose Works of Jonathan Swift, Temple Scott ed., London.

9. Henry St. John, Lord Bolingbroke, Letters and Correspondence, G.G. and J. Robinson, London, 2 vols., I, p. 48.

10. Ibid., I, p. 95 .

11. Ibid., I, p. 118.

12. Davonport, III, p. 141. The French were still negotiating with the Dutch behind the scene. 
13. Bolingbroke, I, p. 186.

14. Davonport, III, p. 148. Bolingbroke, I, 235.

15. Davonport, III, p. 152.

16. Bolingbroke, I, p. 235.

17. Davonport, III, p. 123.

18. Acton, p. 262.

19. Calendar of State Papers (CSP) XVIII, 1700, p. 656, November 15.

20. CSP XVIII, 1700, p. 106 (190) March 6.

21. CSP XVIII, 1700 , p. 658 (936). Gov. Randolph to Council of Trade and Plantations (CTP), Nov. 15.

22. CSP XVIII, 1700, p. 680 (953); XIX, 1701, p. 128 (251), p. 238 (436); XXIV, 1708-1709, p. 169 (226), p. 388 (597), et passim.

23. CSP XXVI, 1711-12, p. 245 (345). Gov. Lord A. Hamilton to CTP, March 18,1712 .

24. CSP XXIII, 1706, p. 280 (524). Gov. Handasyde of Jamaica to CTP, June 10.

25. CSP XX, 1702, p. 5 (6). CTP to the Earl of Nottingham.

26. CSP XXIV, 1708-1709, p. 506 (831). Peter Holt to Capt. William Billton, Oct. 26, 1709.

27. CSP XVIII, 1700 , p. 82 (154). Gov. E. Randolph to CTP, April 10. See also p. 154 (303) and p. 328 (524).

28. CSP XX, 1702, p. 415 (648). Col. Quary in answer to Mr. Penn's complaints, June 23 .

29. CSP XX, 1702, p. 402 (634). Paper by Major Gen. Selwyn, later Governor of Jamaica.

30. CSP XIX, 1701, p. 327 (600). Gov. Codrington to CTP, June 30.

31. Ibid.

32. CSP XX, 1702, p. 226 (342). W. Popple to Charlewood Lawton, April 16.

33. CSP XXII, 1704-1705, p. 308 (643). Lord Cornbury to CTP, Nov. 6 and CSP XX, 1702, p. 611 (999). Lord Cornbury to CTP, Sept. 27. 
34. Donnan, II, pp. 272, 291.

35. Johannes Postma, The Dutch Participation in the African Slave Trade, Michigan State University, Ph.D., 1970; University Microfilms, Ann Arbor, Michigan, p. 117.

36. Ibid. p. 118.

37. Ibid. In the WIC documents this company is referred to also as the Royal Portuguese African Company or the Portuguese Guinea Company.

38. Philip D. Curtin, The African Slave Trade.

39. We put these numbers together from Postma, pp. 231-33.

40. Ibid. These numbers do not take into account the deathrate aboard the slavers during the mid passage.

41. NWIC 200, fol. 43. Gerard Luls to the Board, Aug. 3, 1700.

42. Cornelis Ch. Goslinga, The Dutch in the Caribbean and on the Wild Coast 1580-1680, Gainesville, University of Florida Press, p. 362.

43. In 1700 this three-men committee was composed of Lucas Hansen, Jan Moyaert and Jacob Calvo. The representatives of the asiento at Curaçao were, at that time, Johan Goetvriendt, Philip Henriques and David Senior.

44. NWIC 200, fol. 167-68.

45. Postma, pp. 198 and 63.

46 To overcome these obstacles the Board of X decided, October 18, 1701, to equip a special ship with a cargazoen worth 80,000 guilders to purchase blacks 'like the interlopers'. The experiment failed. See NWIC 1, fol. 56.

47. NWIC 200, fols. 66-67.

48. NWIC 1 , tol. 3 .

49. For the experiences of these ships see NWIC 200, fols. 160-61 and 184 The three slavers were the Croonvogel, the Faam and the West Indische Huis. Jorge Palacios Preciado, La Trata de Negros por Cartagena de Indias, Tunja, Fondo Especial de Publicaciones, Ediciones 'La Rana y El Aguila,' 1973, p. 101, mentions only the Faam (La Fama) with an armazoen of 433 blacks, and the Croonvogel (El Págaro Coronado) with 406 blacks.

50. Davonport, III, p. 40.

51. NWIC 200, fols. 115-16. Van Beek to Board of X, June 21, 1701.

52. NWIC 200, fols. $155 \mathrm{ff}$. 
53. NWIC 200, fols. 226-27.

54. NWIC 1, fol. 81. Board session of Nov. 7, 1701; and 200, fols. 470-72, Van Beek to Board of X, April 4, 1702. The asentistas of Cartagena were over 12,000 pesos behind in payments due to the WIC.

55. NWIC 200, fols. 269-72. Van Beek to Board of X, April 4, 1702.

56. NWIC 200, fols. $340 \mathrm{ff}$. Van Beek to Board of X, June 30, 1702, and fols. 334-37, Van Beek to Board of X, April 24, 1702.

57. NWIC 200, fols. 375 ff. Van Beek to Board of X, Sept. 22, 1702.

58. Ibid., fol. 376 .

59. NWIC 200, fols. 462-63. Van Beek to Board of X, March 8, 1703; 201. fols. $2 \mathrm{ff}$. Gerard Luls to Board of X, April 6, 1703.

60. Don Gaspar de Andrade, the asentista of the Portuguese Company in Cartagena, leaving that port, was caught by Pierre Sirve, a Dutch privateer, and with 50,000 pesos cash brought to Curaçao. Van Beek sent him, the money, and his papers to Amsterdam. NWIC 200, fols. 389-91.

61. NWIC 201, fols. 63-64. Van Beek to Board of X, July 4, 1703.

62. CSP XXI, 1702-1703, p. S (6), Dec. 2, 1702. CTP to Earl of Nottingham.

63. Ibid.

64. CSP XXI, 1702-1703, p. 572 (950), Col. Quary to CTP, July 25, 1703.

65. Ibid., p. 646 (1033), Col. Quary to CTP, August 14, 1703.

66. CSP XXI, 1702-1703, p. 779 (1208), CTP to Earl of Nottingham, Aug. $29,1703$.

67. Ibid.

68. CSP XXI, 1702-1703, p. 711 (1119), Lt. Gov. Handasyde to CTP, Oct. $15,1703$.

69. NWIC 201, fols. 63-64. Van Beek to Board of X, July 4, 1703.

70. Ibid.

71. Ch. Wilson, The Dutch Republic, New York, World Univ. Library, 1968, p. 195.

72. NWIC 201, fols. 83-85. Letter of May 25, 1703.

73. Ibid., fol. 163. Van Beek to Board of X, Sept. 11, 1703. 
74. Scelle II, pp. 285-293.

75. NWIC 201, fol. 246, Van Beek to Board of X, March 1, 1704. See also CSP XXI, 1702-1703, p. 839 (1326), Lt.Gov. Handasyde to Earl of Nottingham, Nov. 27, 1703.

76. NWIC 201, fol. 295.

77. NWIC 201, fol. 247. Van Beek to Board of X, March 1, 1704.

78. Ibid.

79. Ibid.

80. NWIC 201, fols. 258-59. Letter of Oct. 26, 1703.

81. NWIC 201, fols. $284 \mathrm{ff}$. Beck to the Board of X, Aug. 21, 1704.

82. Ibid. Van Tongerloo was a former captain of the WIC.

83. NWIC 201, fols. 306-307. Van Beek to Gov. of Jamaica, Aug. 8, 1704, and CSP XXVIII, 1712-14, p. vii.

84. NWIC 201, fols. 306-307. Van Beek to Board of X, Aug. 8, 1704.

85. NWIC 1, fols. 241-42. Session of the Board of X of March 28, 1705.

86. NWIC 201, fols. 373-400. Beck to Board of X, April 11, 1705.

87. See note 70

88. CSP XXI, 1702-1703, p. 779 (1208), Oct. 29, 1703.

89. CSP XXI, 1702-1703, p. 272 (472). Circular letter from the Earl of Nottingham to the Governors of Her Majesty's Plantations, March 18, 1703.

90. CSP XXII, 1704-1705, p. 49 (116). W. Popple to Richard Warr, Febr. 18, 1704

91. Ibid.

92. Ibid.

93. CSP XXII, 1704-1705, p. 113 (285). May 2, 1704.

94. He was shortly before promoted to governor. See Alan G. Burns, History of British West Indies, London, George Allen \& Unwin Ltd., 2nd ed. 1965, pp. 430-32, and Clinton V. Black, The Story of Jamaica, London, Collins, 1968, pp. 71 and 74 .

95. CSP XXII, 1704-1705, p. 251 (566), Gov. Handasyde to CTP, Sept. 17, 1704 . 
96. CSP XXII, 1704-1705, p. 251 (566). Gov. Handasyde to CTP, Sept. 17, 1704 .

96. NWIC 202, fols. 110-11. Res. of the Raad, Aug. 11, 1705. This resolution was approved by the $\mathrm{X}$ in its session of April 17, 1706. See NWIC 1, 1706, fol. 271.

97. NWIC 1, fol. 269. Session of Board of X, April 17, 1706. See also J.H.J. Hamelberg, De Nederlanders op de West-Indische eilanden, Amsterdam, I, 1901 , p. 113

98. NWIC 1, fol. 304. Session of Board of X, July 14, 1706.

99. NWIC 202, fol. 216. Beck to Board of X, Dec. 9, 1707.

100. NWIC 1, fol. 323. Session of the Board of X, July 21, 1706.

101. NWIC 201, fol. 240. Session of the Board of X, Dec. 1, 1707.

102. Complaints on this low quality were already earlier voiced. See NWIC 1 , fol. 396. Session of Board of X, Nov. 21, 1707; and 202. fols. 391-92. Beck to Board of X, May 26, 1708 .

103. CSP XXV, 1710-11, pp. 326-28 (567). Letter of Dec. 26, 1710. See also p. 17 (48-52), Jan. 9, 1710, and pp. 91-98 (228), Gov. Parks of Antigua to CTP, May 11, 1710 .

104. CSP XXIV, $1708-1709$, p. 532 (872) CTP to Gov. Handasyde, Nov. 25, 1709.

105. CSP XXIV, 1708-1709, p. 95 (134), Earl of Sunderland to CTP, Sept. 14 1708 .

106. The French, at that time, seemed to have three African companies: the Company of Guinea, of Senegal, and of St. Domingue. See Palacios, La Trata de Negros por Cartagena de Indias, p. 128. See also NWIC 1, tol. 417. Session of the Board of X, Nov. 30, 1707.

107. NWIC 202, fol. 431. Luls to Board of X, May 25, 1708

108. NWIC 202, fols. 372-73. Beck to Board of X, May 26, 1708.

109. Ibid.

110. Ibid. Sessions of the Raad of March 13 and 19, 1708.

111. Gov. Beck trespassed Company's regulation by paying the crews of the two slavers the Elmina and the Adrichem some wages - resp. Ps. 264 and 365 to buy new clothes to replace their raghs. He was severely reprimanded by the Board. NWIC 202,fol. 461. Van Collen to Board of X, Jan. 31, 1709. 
112. NWIC 3, fol. 95. See on the Van Collen family Johan E. Elias, Geschiedenis van het Amsterdamsche Regentenpatriciaat, 's-Gravenhage, 1923.

113. NWIC 2, fol. 48. Session of Board of X, Nov. 15, 1708; 202, fols. 577-78. Van Collen to Board of X, June 8, 1709.

114. NWIC 202, fols. 372 ff. Beck to Board of X, May 26, 1708.

115. NWIC 2, fol. 197. Session of Board of X, Sept. 19, 1710.

116. NWIC 2, fol. 201. Session of Board of X, Sept. 22, 1710.

117. NWIC 202, fol. 580. Van Collen to Board of X, June 8, 1709.

118. NWIC 202, fol. 583. Res. of Raad, June 1 and 2, 1709. Some gold was also confiscated together with another nine Piezas de India and Ps. 1884 in cash.

119. NWIC 202, fols. 590-99, 601-602.

120. NWIC 203, fols. 1-2. Beck to Board of X, July 13, 1709.

121. NWIC 203, fols. 124-25. Declaration of Van Collen, July 5, 1709.

122. NWIC 203, fols. 186-88. Request of July 17, 1709.

123. NWIC 203, fol. 206. Request of July 24, 1709.

124. NWIC 203, fol. 206-207.

125. NWIC 203, fols. 283 and 211-14.

126. NWIC 203, fol. 290 and 370. Beck to Board of X, Jan. 1710. Fol. 310, Res. of the Raad, Sept. 4, 1709.

127. NWIC 203, fol. 290 and fols. 374-75. Session of Raad, Oct. 15, 1709.

128. NWIC 203, fol. 513. Minutes of the Raad. Placards were issued June 11, July 9, and July 29,1710 .

129. NWIC 203, fol. 375 .

130. NWIC 203, fol. 595. Postma, pp. 234 and 237.

131. NWIC 203, fols. 627-28.

132. NWIC 204, fols. 1-36. Van Collen to Board of X, March, 1711.

133. NWIC 204, fols. 52-53, 56-64 and 150-51. Van Collen to Board of X, March 17, 1711. 
134. NWIC 204, fols. 340-43. Van Collen to Board of X, June 30, 1711; and fol. 465. Van Collen to Board of X, April 12, 1712. The one slaver that arrived was the Honaart (called by Postma Homert).

135. NWIC 204, fols. 467-69. Van Collen to the Board of X, April 12, 1712. Van Collen was officially inaugurated as governor, being appointed by the Board in its session of Dec. 5, 1711. The Venezuelan governor was José L. de Cañas y Merino, born in Africa of Spanish parents and an active persecutor of the contraband trade. See Luis A. Sucre, Gobernadores y capitanes generales de Venezuela, Caracas, 1964, pp. 207-13. Documents in NWIC 204 are missing from June 30, 1711 to April 12, 1712. Postma's study indicates that no slavers with destination Curaçao left Africa during this period.

136. NWIC 205, fol. 20. Van Collen to Board of X, May 17, 1713. Another slaver which arrived in this year, the Clara changed its destination Surinam for Curaçao after hearing that the French under Cassard were operating in the Guianas area. See fol. 379. Van Collen to Board of X, May 18, 1713. Piezas de India were sold in public auction for a little over Ps. 108.

137. This was the Adrichem. See NWIC 205, fols. 417-26. Van Collen to Board of X, Febr. 10, 1714.

138. NWIC 205, fols. 585 ff. Van Collen to Board of X, Jan. 18, 1715.

139. NWIC 205, fols. 626-31. De Bij to Board of X, June 12, 1714; fols. 638-40. De Bij to Board of X, Nov. 27, 1714.

140. NWIC 206, fols. 73-76. De Bij to Board of X, July 4, 1715.

141. NWIC 206, fols. 101-102. De Bij to Board of X, Aug. 3, 1715.

142. NWIC 1, fol. 97.

143. NWIC 3, fols. 86-93.

144. NWIC 3, fols. 233-238. Session Nov. 3, 1713.

145. The Curaçao slave trade did not end as abruptly as Postma's study indicates. For 1716 Postma gives only one slaver with destination Curaçao, the $\mathrm{Gel}$ derland. In reality four slavers dropped anchor in Willemstad in the course of that year: the Nieuwe Post with 467 blacks out of 513; the Fida with 241 blacks out of 257; Vlissings Welvaren with 194 slaves (no deaths!); and the Gelderland (mentioned by Postma p. 236) with 141 blacks out of 146. In 1717, only one slaver, the Emmenes, arrived with 449 blacks. Our research ended there.

If we must believe Postma, the ten years, from 1716 to 1725 , saw only three slavers in Willemstad.

prof. dr. C. Ch. Goslinga, Center for Latin American Studies, University of Florida, Gainsville, Fla. 32601. 


\section{REFERENCES}

The materiel for this article was mainly found in ARA (Algemeen Rijksarchief), The Hague in the following items:

Nieuwe West Indische Compagnie (New West India Company, NWIC), no. $1,2,3,4,5$, and 6 , and no. 200, 201, 202, 203, 204, 205, 206. The first books contain the minutes of the sessions of the Board of X during the years 1700 through 1716, the second collection of books contain the letters and other information sent by the governors and other officials of the WIC in Curacao to the Board of $\mathrm{X}$ over the same period.

Annaboa
Vergulde Vrijheyt
Wapen van Holland
Eva Maria
Quinira (or Jufvrouw Quinira)
Margarethe Catharina
Vergulde Son (or Son)
Rachel
Duynenburgh
Vrientschap
Elmina
Beurs van Amsterdam
Hollandia
Vergulde Son (or Son)
Duynenburgh
Beurs van Amsterdam
Wakende Craan
Coninck van Portugal
Vergulde Son (or Son)
Carolus Secundus
Elmina
Adrichem
Quinira (or Jufvrouw Quinira)
Axim
Carolus Secundus
Adrichem
St. Clara (or Clara)
St. Marcus
Coninginne Hester
Adrichem
Fmmenes
Sonnesteyn
Engelenburgh
Nieuwe Post
Fida
Vlissings Welvaren
Gelderland

NWIC 200, fol. 70.

fols. $99,113,369$.

fols. 155-56, 168-71, 188.

fols. $157,187,206-208$.

fols. 222, 231, 244-45.

fols. $262-69,275,370$.

fols. $269,287,370$.

fols. $269,297,372$.

NWIC 201, fols. 176-77.

fols. 328,345 .

fol. 473 .

fols. $480-83$.

NWIC 202, fol. 41 .

fols. 146-49.

fols. 141,146 .

fol. 174 .

fol. 175 .

fols. 198, 224, 342-45.

fols. 284,349 .

fols. 377,391 .

fols. $460,478-87,554$.

fols. $461,494,554$.

fols. 573-74, 627-28.

fol. 545 .

fol. 553 .

NWIC 205, fol. 438.

fol. 338 .

fol. 425 .

fols. $638-40,643$.

NWIC 206, fols. 73-74, 78-79.

fols. 74, 92-96.

fols. 103-104.

fols. 114,146

fols. 175-76.

fols. 178-80.

fol. 218.

fols. 223-24, 226 . 
The Curaça slave trade during the War of the Spanish Succession

\begin{tabular}{|c|c|c|c|c|c|c|c|}
\hline & Port of & Date of & & Date of & & r of blacks & \\
\hline Ship & & & Destination & $\frac{\text { arrival }}{?}$ & $\frac{\text { embarked }}{488}$ & $\begin{array}{ll} & \text { disembarked } \\
362 & \end{array}$ & $\frac{\mathrm{P}=\mathrm{Postm} i}{\mathrm{P} .236}$ \\
\hline Graaf van Laarwijk & Fida & April 1700 & Cartagena & Jan. 1701 & 566 & $\left.406^{1}\right)$ & P. 236 \\
\hline Croonvogel & Fida & May 1700 & Cartagena & Sept. 28,1700 & 110 & 68 & P. 234 \\
\hline Annaboa & Elmina & June 1700 & Curaçao & Oct. 25,1700 & 565 & ? & P. 23 \\
\hline Beschermer & Fida & Aug. 1700 & Cartagena & March 4, $\left.1701^{2}\right)$ & 762 & 647 & not in $\mathrm{P}$. \\
\hline West Indisch Huis & ? & ? & Cartagena & March 9, 1701 & 694 & 669 & not in $\mathrm{P}$ \\
\hline Vergulde Vrijheyt & Loango/Boary & ? & Curaçao & ? & 505 & $\left.433^{3}\right)$ & not in $\mathrm{P}$ \\
\hline Faam & Elmina & ? & Cartagena & June 25,1701 & 664 & 459 & not in $P$ \\
\hline Wapen van Holland & Ardra & Nov. 1700 & Curaçao & June? 1701 & 136 & $\left.124^{4}\right)$ & P. 236 \\
\hline Jager & $?$ & Jan. 1701 & Curaçao & July 28,1701 & 644 & 588 & not in $P$ \\
\hline Eva Maria & Loango/Boary & ? & Curaçao & Aug. 11, 1701 & 499 & 430 & not in $P$ \\
\hline Quinira & Ardra & ? & Curaçao & Nov. 20,1701 & 443 & 386 & not in $P$ \\
\hline Margaretha Catharina & Loango/Boary & ? & Curaçao & Dec. 11,1701 & 369 & 315 & not in $P$ \\
\hline Vergulde Son & Ardra & ? & Curaçao & Jan. 24,1703 & 419 & 331 & P. 237 \\
\hline Rachel & Fida & June 1703 & Curaçao & March 4, 1703 & 542 & 502 & not in $P$ \\
\hline Duynenburgh & Angola & ? & Curaçao & Aug. 6, 1704 & 393 & 314 & P. 238 \\
\hline Vrientschap & Elmina/Fida & Febr. 1704 & Curaçao & Dec. 2,1704 & 171 & 158 & P. 235 \\
\hline Elmina & Elmina/Moure & Oct. 1704 & Curaçao & Jan. 5, 1705 & 653 & 615 & not in $P$ \\
\hline Beurs van Amsterdam & Loango/Molemba & $?$ & Curaçao & May 13,1705 & 712 & 557 & not in $P$ \\
\hline Hollandia & Loango/Molemba & ? & Curaçao & Oct. 12,170 s & 694 & 559 & not in $P$ \\
\hline Son & Loango/Molemba & ? & Curaçao & & & & \\
\hline
\end{tabular}




\begin{tabular}{|c|c|c|c|c|c|c|c|}
\hline Ship & $\begin{array}{l}\text { Port of } \\
\text { departure }\end{array}$ & $\begin{array}{l}\text { Date of } \\
\text { departure }\end{array}$ & Destination & $\begin{array}{l}\text { Date of } \\
\text { arrival }\end{array}$ & embarked & $\begin{array}{l}\text { disembarked } \\
\text { disems }\end{array}$ & $\mathrm{P}=\mathrm{Pos}$ \\
\hline Duynenburgh & Fida & Aug. 1705 & & Nov. 14,1705 & 473 & 399 & P. \\
\hline Quinira & Accra & March 1706 & Curaçao & May $25,1706^{4}$ ) & 547 & 394 & P. \\
\hline Beurs van Amsterdam & Loango/Molemba & April 1706 & Curaçao & Oct. 25,1706 & 705 & & \\
\hline Moscow & Fida & Oct. 1706 & Curaçao & Oct. 25,1706 & 705 & 626 & P. \\
\hline Wakende Craan & Elmina & Oct. 1706 & Curaçao & diverted to Essequibo ${ }^{4}$ ) & 571 & & P. \\
\hline Catharina Christina & Accra & Dec. 1706 & Curaçao & Nov. 30,1706 & 190 & 177 & P. \\
\hline Duynenburgh & $?$ & April 1707 & Curaçao & March 11, $1707^{4}$ ) & 540 & 507 & P. \\
\hline Coninck van Portugal & Ardra/Fida & July 1707 & Curaçao & never arrived & 559 & & P. \\
\hline Son (or Vergulde Son) & Fida & Sept. 1707 & Curaçao & Oct. 31,1707 & 536 & 428 & P. \\
\hline Carolus Secundus & Elmina & Nov. 1707 & Curaçao & Dec. 30,1707 & 558 & 417 & P. \\
\hline Elmina & Elmina & $?$ & Curaçao & Febr. 15,1708 & 425 & 171 & P. \\
\hline St. Jago & Fida & July 1708 & Curaçao & Nov. 18,1708 & 196 & 182 & not \\
\hline Adrichem & Fida & ? & Curaçao & never arrived & 200 & & $\mathrm{P}$ \\
\hline Quinira & Fida & Febr. 1709 & Curaçao & Nov 27,1708 & 612 & 462 & not \\
\hline Amsterdam & Fida & Jan. 1710 & Curaçao & May 12,1709 & 530 & 464 & P. \\
\hline A frica $^{5}$ ) & Fida & May 1710 & Curaçao & never arrived & 483 & & P. \\
\hline Axim & Elmina & $?$ & Curaçao & never arrived & 195 & & P. \\
\hline Carolus Secundus & Fida & Oct. 1710 & Curaçao & Oct. 10,1710 & 139 & 83 & ot \\
\hline Moscow $\left.{ }^{6}\right)$ & $\mathrm{Aja}$ & Oct. 1710 & Curaçao & Dec. 7,1710 & 490 & 458 & . \\
\hline Axim $^{7}$ ) & $?$ & June 1711 & Curaçao & never arrived & 572 & & \\
\hline Honaert $^{8}$ ) & Fida & June 1711 & Curaçao & never arrived & $?$ & & P. \\
\hline Acredam ${ }^{9}$ ) & Fida & June 1712 & Curaçao & $\begin{array}{l}\text { Dec. } 7,1711 \\
\text { diverted to Surinam }\end{array}$ & $\begin{array}{l}? \\
570\end{array}$ & 584 & $\mathrm{P}$ \\
\hline
\end{tabular}




\begin{tabular}{|c|c|c|c|c|c|c|c|}
\hline \multirow{2}{*}{$\begin{array}{l}\text { Date of } \\
\text { arrival }\end{array}$} & \multicolumn{2}{|c|}{ Number of blacks } & \multirow[b]{2}{*}{$\mathrm{P}=$ Postma } & \multirow[b]{2}{*}{ Ship } & \multirow{2}{*}{$\begin{array}{l}\text { Port of } \\
\text { departure }\end{array}$} & \multirow{2}{*}{$\begin{array}{l}\text { Date of } \\
\text { departure }\end{array}$} & \multirow[b]{2}{*}{ Destinati } \\
\hline & embarked & disembarked & & & & & \\
\hline April 30,1712 & 611 & 570 & not in $P$. & Adrichem & Fida & $?$ & Curaçao \\
\hline Nov. 16,1712 & 584 & 452 & P. 235 & St. Clara (or Clara) & Fida & Sept. 1712 & Curaçao \\
\hline Jan. 12, 1714 & 585 & 556 & P. 237 & St. Marcus & Fida & Nov. 1713 & Curaçao \\
\hline diverted to Surinam ${ }^{9}$ ) & 596 & & P. 234 & Acredam & Fida & March 1714 & Curaçao \\
\hline Sept. 17,1714 & $\left.620^{11}\right)$ & 466 & P. 236 & Coninginne Hester & Fida & April 1714 & Curaçao \\
\hline diverted to Surinam ${ }^{4}$ ) & 541 & & P. 236 & Guntersteyn & Fida & April 1714 & Curaçao \\
\hline June 26,1715 & 717 & 373 & not in $P$. & Adrichem & Loango/Boary & $?$ & Curaçao \\
\hline July 9, 1715 & 563 & 459 & P. 235 & Emmenes & Fida & March 1715 & Curaçao \\
\hline Sept. 2, 1715 & 102 & 66 & not in $P$. & Sonnesteyn & Elmina & $?$ & Curaçao \\
\hline Dec. 10,1715 & 153 & 136 & P. 235 & Engelenburgh & Elmina & Oct. 1715 & Curaçao \\
\hline Febr. 9, 1716 & 559 & 513 & not in $P$. & Nieuwe Post & Angola & $?$ & Curaçao \\
\hline Febr. 9, 1716 & 257 & 241 & P. 236 & Fida & Elmina & Dec. 1715 & Curaşao \\
\hline March 13, 1716 & 194 & 194 & not in $P$. & Vlissings Welvaren & Loango & $?$ & Curaçao \\
\hline June 7, 1716 & 146 & 141 & P. 236 & Gelderland & Elmina & April 1716 & Curaçao \\
\hline
\end{tabular}


1) Postma's date of the Crnonvogel's departure must be wrong. If this ship (also spelled Kroonvogel) left the West African coast in May, 1700 , and passed Curaçao in January, 1701, the crossing of the Atlantic would have required an incredible eight months. Postma gives an armazoen of 500 blacks; when it passed Curaçao it carried 495 (NWIC 200, fol. 67). It disembarked in Cartagena only 406 (see Palacios, p. 101).

2) The West Indisch Huis passed Curaçao March 4, 1701, on its way to Cartagena.

3) The Faam passed Curaçao March 28, 1701, with 436 blacks out of an armazoen of 505

4) Information given by Postma in private correspondence.

5) The Africa probably never crossed the Atlantic. Information given by Postma in private correspondence.

6) The Moscow is an error of Postma, p. 237. Information given by Postma in private correspondence.

7) The Axim, P. p. 234 idem.

8) The Honaert (or Honaart) arrived Dec. 7, 1711 and disembarked 584 blacks. Information given by Postma in private correspondence.

9) The Acredam was diverted to Surinam. Idem.

10) The destination of the St. Clara was originally Surinam. Because of French privateering under Cassard it was diverted to Curaçao.

11) Postma, p. 236 gives an armazoen of $617^{1 / 2}$.

In the period from 1700 through 171656 Dutch slavers crossed the Atlantic with destination Cartagena or Curaçao. Of these 56 slavers 20 are not mentioned by Postma. Five had Cartagena as their destination. Postma mentions only three. Of the 51 with destination Curaçao private correspondence with Postma revealed that four were diverted to the Guianas. Of the 47 slavers left six never dropped anchor in Willemstad. Of the remaining 41 Postma mentions only 23.

However in private correspondence with Postma the latter revealed that he has completed much additional research (of which some is included in this article as mentioned above). Consequently his (xeroxed) dissertation will be completely revised and hopefully soon published. 
Sales of Slaves in Curaço 1700-1716

Number

Deliverable slaves

Mancquerons

Public auctions

\begin{tabular}{|c|c|c|c|c|c|c|c|}
\hline \multicolumn{2}{|c|}{ of slaves } & Number & Piezas & \multicolumn{2}{|c|}{ and sick slaves } & Number & Amount \\
\hline Annaboa & 68 & 30 & $245 / 6$ & Ps. $2,483.2 .4$ & 38 & 38 & Ps. 2,245 \\
\hline Vergulde Vrijheyt & 669 & 556 & 482 & Ps. 46,754 & 113 & 113 & Ps. $7,584.5 .2$ \\
\hline Wapen van Holland & 459 & 257 & $2391 / 3$ & Ps. $23,233.5 .4$ & 202 & 197 & Ps. $11,936.2$. \\
\hline Eva Maria & 588 & 441 & $378 s / 6$ & Ps. $37,883.4$ & 147 & 133 & Ps. $7,563.4$ \\
\hline Quinira & 430 & 227 & $2141 / 3$ & Ps. 21,433 & 203 & 185 & Ps. 7,914.2. \\
\hline Jager & 124 & ? & ? & $?$ & $?$ & 45 & Ps. 2,284 \\
\hline Margaretha Catharina & 386 & 302 & $2631 / 3$ & Ps. $26,333.4$ & 84 & & \\
\hline Vergulde Son & 315 & 237 & $2315 / 6$ & Ps. $23,783.4$ & $\begin{array}{l}84 \\
78\end{array}$ & $\begin{array}{l}83 \\
77\end{array}$ & $\begin{array}{ll}\text { Ps. } & 3,526.1 .2 \\
P_{s} & 365\end{array}$ \\
\hline Rachel & 331 & 220 & $2131 / 6$ & Ps. $21,316.8$ & 111 & $\begin{array}{r}77 \\
125\end{array}$ & Ps. 3,765 \\
\hline Duynenburgh & 502 & 354 & $3055 / 6$ & Ps. $30,583.4$ & 148 & 125 & Ps. 5,511 \\
\hline Vrientschap & 314 & 228 & $2145 / 6$ & Ps. $21,483.4$ & 86 & 138 & Ps. 7,354.3 \\
\hline Elmina & 158 & 102 & 101 & Ps. 10,100 & 56 & $\begin{array}{l}79 \\
56\end{array}$ & Ps. $\quad 5,582.4$ \\
\hline Beurs van Amsterdam & 615 & 468 & $4121 / 6$ & Ps. $41,216.8$ & 167 & 56 & Ps. $5,250.4$ \\
\hline Hollandia & 557 & 333 & $2975 / 6$ & Ps. $29,783.4$ & 224 & 147 & Ps. 9,873 \\
\hline Son (or Vergulde Son) & 559 & 431 & $380 s / 6$ & & 128 & 224 & Ps. $12,681.4$ \\
\hline & & & 301 a Ps. 100 & Ps. $30,183.4$ & 128 & 128 & Ps. 7,560 \\
\hline & & & 79 a Ps. 108 & Ps. 8.622 & & & \\
\hline Duynenburgh & 399 & 347 & $3311 / 6$ & Ps. $30,583.4$ & 52 & 52 & Ps. $4,212.4$ \\
\hline Quinira & 394 & $?$ & $?$ & $?$ & $?$ & 72 & PS. 4,212.4 \\
\hline Beurs van Amsterdam & 626 & ? & $4751 / 3$ & Ps. 51.136 & $?$ & 23 & Ps. 1.909 \\
\hline Wakende Craan & 177 & 120 & 120 & Ps. 12.960 & 57 & $?$ & 13. 1.707 \\
\hline Catharina Christina & 507 & $?$ & $?$ & $?$ & $?$ & & \\
\hline Coninck van Portugal & 428 & 327 & 327 & Ps. 35.316 & 101 & 101 & Ps. 7.020 .4 \\
\hline
\end{tabular}




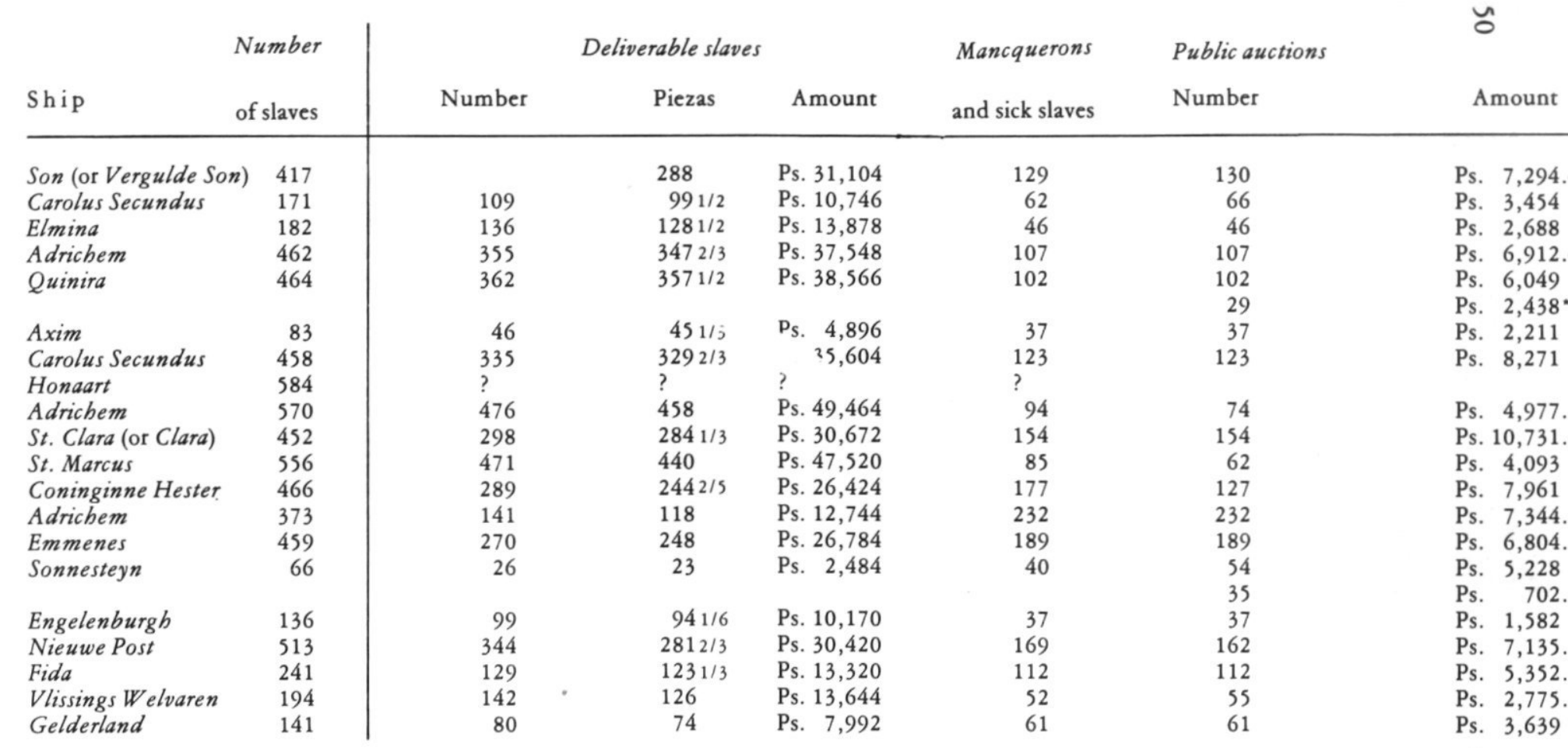

